OPEN ACCESS

Edited by:

Mariano Pérez-Filgueira,

National Agricultural Technology

Institute, Argentina

Reviewed by:

Charles K. Nfon,

National Centre for Foreign Animal

Disease (NCFAD), Canada

Sabrina Galdo Novo,

University of Buenos Aires, Argentina

*Correspondence:

Melanie Chitray

chitraym@arc.agric.za

Specialty section:

This article was submitted to Veterinary Infectious Diseases,

a section of the journal

Frontiers in Veterinary Science

Received: 16 April 2020

Accepted: 25 June 2020

Published: 11 August 2020

Citation:

Chitray M, Opperman PA,

Rotherham L, Fehrsen J, van Wyngaardt W, Frischmuth J,

Rieder E and Maree FF (2020)

Diagnostic and Epitope Mapping

Potential of Single-Chain Antibody

Fragments Against Foot-and-Mouth

Disease Virus Serotypes A, SAT1, and

SAT3. Front. Vet. Sci. 7:475.

doi: 10.3389/fvets.2020.00475

\section{Diagnostic and Epitope Mapping Potential of Single-Chain Antibody Fragments Against Foot-and-Mouth Disease Virus Serotypes A, SAT1, and SAT3}

\author{
Melanie Chitray 1,2*, Pamela Anne Opperman ${ }^{1,3}$, Lia Rotherham ${ }^{1}$, Jeanni Fehrsen ${ }^{1,2}$, \\ Wouter van Wyngaardt ${ }^{1}$, Janine Frischmuth ${ }^{4}$, Elizabeth Rieder ${ }^{5}$ and \\ Francois Frederick Maree ${ }^{1,6}$
}

${ }^{1}$ Agricultural Research Council, Onderstepoort Veterinary Research, Vaccines and Diagnostic Development, Onderstepoort, Pretoria, South Africa, ${ }^{2}$ Department of Veterinary Tropical Diseases, Faculty of Veterinary Science, University of Pretoria, Pretoria, South Africa, ${ }^{3}$ Department of Production Animal Studies, Faculty of Veterinary Science, University of Pretoria, Pretoria, South Africa, ${ }^{4}$ Biotechnology Division, National Bioproducts Institute, Pinetown, South Africa, ${ }^{5}$ Plum Island Animal Disease Centre, U.S. Department of Agriculture, Agricultural Research Service, Greenport, NY, United States, ${ }^{6}$ Department of Biochemistry, Genetics and Microbiology, Faculty of Natural and Agricultural Sciences, University of Pretoria, Pretoria, South Africa

Foot-and-mouth disease (FMD) affects cloven-hoofed domestic and wildlife animals and an outbreak can cause severe losses in milk production, reduction in meat production and death amongst young animals. Several parts of Asia, most of Africa, and the Middle East remain endemic, thus emphasis on improved FMD vaccines, diagnostic assays, and control measures are key research areas. FMD virus (FMDV) populations are quasispecies, which pose serious implications in vaccine design and efficacy where an effective vaccine should include multiple independent neutralizing epitopes to elicit an adequate immune response. Further investigation of the residues that comprise the antigenic determinants of the virus will allow the identification of mutations in outbreak strains that potentially lessen the efficacy of a vaccine. Additionally, of utmost importance in endemic regions, is the accurate diagnosis of FMDV infection for the control and eradication of the disease. To this end, a phage display library was explored to identify FMDV epitopes for recombinant vaccines and for the generation of reagents for improved diagnostic FMD enzyme-linked immunosorbent assays (ELISAs). A naïve semi-synthetic chicken single chain variable fragment (scFv) phage display library i.e., the $N k u k u^{\circledR}$ library was used for bio-panning against FMD Southern-African Territories (SAT) 1, SAT3, and serotype A viruses. Biopanning yielded one unique SCFV against SAT1, two for SAT3, and nine for A22. SAT1 and SAT3 specific scFvs were exploited as capturing and detecting reagents to develop an improved diagnostic ELISA for FMDV. The SAT1 soluble scFv showed potential as a detecting reagent in the liquid phase blocking ELISA (LPBE) as it reacted specifically with a panel of SAT1 viruses, albeit with different ELISA absorbance signals. The SAT1svFv1 had little or no change on its paratope when coated on polystyrene plates whilst the SAT3ScFV's paratope may have changed. SAT1 and SAT3 soluble scFvs did not neutralize the SAT1 and SAT3 viruses; however, three 
of the nine A22 binders i.e., A22scFv1, A22scFv2, and A22scFv8 were able to neutralize A22 virus. Following the generation of virus escape mutants through successive virus passage under scFv pressure, FMDV epitopes were postulated i.e., RGD+3 and +4 positions respectively, proving the epitope mapping potential of scFvs.

Keywords: foot-and-mouth disease, SAT1, SAT3, serotype A, phage display, single-chain variable fragment, epitope, ELISA

\section{INTRODUCTION}

Diseases caused by RNA viruses are often difficult to control because of the high mutation rate and the continual emergence of novel genetic and antigenic variants that allow escape from immunity (1). Antigenic differences between viruses play a role in whether the immunity induced by one virus is effective against another. Foot-and-mouth disease (FMD) virus (FMDV), a singlestranded, positive-sense RNA virus, and the prototype member of the Aphthovirus genus in the family Picornaviridae (2), is an example of an antigenically variable pathogen with the ability to evade the immune system (3-5). Of the seven clinically indistinguishable FMDV serotypes, viruses belonging to the three Southern African Territories (SAT) serotypes display appreciably greater genomic and antigenic variation (6).

Two key research focus areas for enhanced FMD control are improved vaccines that offer a broad immunogenic response and improved specific diagnostic assays (7). However, the high antigenic diversity that exists within the FMDV serotypes hinders FMD control by vaccination, as vaccination against one serotype does not confer protection against another and may only be partially effective against some subtypes within the same serotype (8). This poses serious implications in vaccine design and efficacy where an effective vaccine should include multiple independent epitopes to elicit an immune response (9). The humoral immune response has generally been accepted as the most important factor in conferring vaccine-induced protection against FMD, as a strong correlation has been reported between the levels of virus-neutralizing antibody produced after vaccination and subsequent protection of cattle, one of the main target species for vaccination (10-13). To develop more effective vaccines or peptide vaccines, numerous FMDV studies have been undertaken to identify these neutralizing antigenic sites in more detail (14). Neutralizing antigenic sites have been identified for serotype A (15-17), O (18-21), C (22), Asia-1 (23), and SAT2 (19, 24, 25). However, information regarding the antigenic determinants of SAT serotypes, which are confined geographically to Africa, is scarce (26). Mapped SAT2 epitopes include: (i) $\beta \mathrm{G}-\beta \mathrm{H}$ loop of VP1; (ii) residue 210 in the C-terminus of VP1; (iii) VP1 8486, 109-111, VP2 71, 72, 133, 134; and (iv) VP1 159, VP2 71$72,133-134,148-150(19,24,25,27,28)$. Four independent antigenic determinants were identified for SAT1 viruses i.e., (i) two occurring in the $\beta \mathrm{G}-\beta \mathrm{H}$ loop of VP1; (ii) two simultaneous residues one in VP3 (position 135 or 71 or 76 ) and one in VP1 (position 179 or 181); (iii) a conformation dependant site

Abbreviations: FMD, foot-and-mouth disease; FMDV, FMD virus; scFv, singlechain variable fragment; $\mathrm{MAb}$, monoclonal antibody. within VP1 position 181 and VP2 72; and (iv) VP1 position 111 (24). To date, no neutralizing sites have been determined for viruses of the SAT3 serotype. It has been shown that the majority of FMDV-neutralizing antibodies are directed against conformational epitopes located on the $\beta$-barrel connecting loops, especially the highly mobile $\beta \mathrm{G}-\beta \mathrm{H}$ loop in $\mathrm{VP} 1(15,18$, $26,29,30)$. Therefore, knowledge of the amino acid residues that comprise the antigenic determinants of FMDV, and those that function as protective epitopes in particular, will greatly improve our understanding of virus neutralization in vivo $(12,26,31)$.

Diagnostic assays hampered by the lack of specificity caused by polyclonal capture and detection antibodies highlighted the need for more specific tests. Monoclonal antibodies are highly specific reagents and are being used for a variety of research and diagnostic purposes within the FMD field and their pivotal role in all aspects of FMD research is now clear. However, traditional monoclonal antibodies, produced using hybridoma technology, and used in diagnostics have several limitations such as its high cost, time-consuming production, and the expertise required (32-34).

The development of large combinatorial antibody libraries based on antibody genes expressed and displayed on phages have revolutionized the selection and isolation of unique antibodies to an antigen and aided in the development of recombinant reagents for ELISA (35). A key advantage of phage display of antibody fragments is that the generation of specific singlechain variable fragment ( $\mathrm{scFv}$ ) or antigen binding fragment $(\mathrm{Fab})$ to a particular antigen can be completed within a few weeks compared to hybridomas taking months. Antibody libraries can be either immune (from immunized donors) or naïve (from non-immunized donors). An immune library will have an antibody range that is highly enriched for antibodies generated in response to a particular immunogen, whereas, the naïve library can advantageously be used for an unlimited array of immunogens (36).

Phage display libraries have been used with success to map epitopes for FMDV for serotype O $(37,38)$ and the SAT2 serotype (25). The $N k u k u^{\circledR}$ phage-display library, which is a large semisynthetic library of recombinant filamentous bacteriophages displaying scFv's derived from combinatorial pairings of chicken variable heavy and light chains, was used for this study (36). This naïve library has been utilized to generate a variety of antibodies against antigens such as the bluetongue virus, African horse sickness virus, echovirus 1, coxsackievirus B3, FMDV of the SAT2 serotype as well as a mycobacterial $16 \mathrm{kDa}$ antigen $(25,36,39-$ 42). These studies prove that this library is sufficiently diverse for the recognition of a variety of different haptens, proteins, bacteria, and viruses. 
In this study, phage display technology was used to obtain specific scFvs from panning with FMDV serotype A, SAT1, and SAT3 viruses. This is a novel study as recombinant monoclonal antibodies (scFvs) have not been isolated for FMDV serotype A, SAT1, and SAT3. The scFvs resulting from the biopanning were investigated in virus neutralization assays in the pursuit of epitope identification and for their prospective use as FMDV diagnostic reagents in an ELISA.

\section{MATERIALS AND METHODS}

\section{Cell Cultures, Virus Propagation, and Purification}

Baby hamster kidney (BHK) strain 21 clone 13 cells (ATCC CCL10), used for virus propagation and SAT1 and SAT3 serotype neutralization assays, were maintained in Glasgow minimum essential medium (GMEM, Sigma-Aldrich), supplemented with $10 \%(\mathrm{v} / \mathrm{v})$ fetal bovine serum (FBS, Hyclone), $1 \times$ antibiotic-antimycotic solution (Invitrogen), $1 \mathrm{mM}$ L-glutamine (Invitrogen), and $10 \%(\mathrm{v} / \mathrm{v})$ tryptose phosphate broth (TPB, Sigma-Aldrich. Instituto Biologico Renal Suino-2 (IBRS-2) cells used for A22 virus propagation and virus neutralization tests, were maintained in Roswell Park Memorial Institute (RPMI) medium (Sigma-Aldrich) supplemented with $10 \%$ $(\mathrm{v} / \mathrm{v})$ fetal bovine serum (FBS, Hyclone) and $1 \times$ antibioticantimycotic solution (Invitrogen). The Mycl-9E10 hybridoma (ECACC 85102202) was cultured in protein-free hybridoma medium (Invitrogen).

The SAT1/KNP/196/91 and SAT3/KNP/10/90 FMDVs used for the biopanning, originated from buffalo in the Kruger National Park (KNP) in South Africa, isolated during 1991 and 1990, respectively (Table 1). Also used for biopanning was the A22 virus (Table 1), which was obtained from the Pirbright Institute, UK. The SAT1 and SAT3 viruses were propagated on BHK-21 cells whilst A22 was propagated on IB-RS-2 cells prior to sucrose density gradient (SDG) purification of $146 \mathrm{~S}$ particles. Virus particles were concentrated with $8 \%(\mathrm{w} / \mathrm{v})$ polyethylene glycol (PEG)-8000 (Sigma-Aldrich) and purified on 10-50\% $(\mathrm{w} / \mathrm{v})$ sucrose density gradients, prepared in TNE buffer $(50 \mathrm{mM}$ Tris pH 7.4, $150 \mathrm{mM} \mathrm{NaCl}, 10 \mathrm{mM}$ EDTA), as described by Knipe et al. (43). Peak fractions corresponding to $146 \mathrm{~S}$ virion particles (extinction coefficient E259 nm [1\%] = 78.8) were pooled and the amount of antigen $(\mu \mathrm{g})$ was calculated as described previously (44). In a similar way, viruses utilized for the ELISA assays (Table 1) were PEG concentrated, where virus particles were concentrated with $8 \%(\mathrm{w} / \mathrm{v})$ PEG-8000 (Sigma-Aldrich) and the resulting precipitated pellet was re-suspended in TNE buffer.

\section{Selection of scFvs Against SAT1/KNP/196/91, SAT3/KNP/10/90, and A22}

Selection of virus-specific scFvs from the $N k u k u^{\circledR}$ phage display library was performed as described by van Wyngaardt et al. (36) and Opperman et al. (25). Briefly, 2-ml immunotubes (Nunc ${ }^{\circledR}$ Maxisorp), after being coated overnight with purified virus $(30 \mu \mathrm{g} / \mathrm{ml})$ were blocked with $1 \times$ PBS containing $2 \%(\mathrm{w} / \mathrm{v})$
TABLE 1 | Detailed list of FMDV SAT1, SAT2, SAT3, and A viruses used in this study.

\begin{tabular}{|c|c|c|c|}
\hline FMDV Serotype & Virus strain & Passage history ${ }^{\star}$ & $\begin{array}{l}\text { Genbank } \\
\text { accession } \\
\text { number }\end{array}$ \\
\hline \multirow[t]{11}{*}{ SAT1 } & KNP/196/91 & PK1RS5 & DQ009716 \\
\hline & $\mathrm{KNP} / 3 / 03$ & PK1RS1 & KJ999914 \\
\hline & $\mathrm{SAR} / 33 / 00$ & PK1RS2 & KJ999908 \\
\hline & BOT/1/06 & PK1RS1 & KJ999919 \\
\hline & $\mathrm{SAR} / 9 / 03$ & PK1RS1 & KJ999911 \\
\hline & $\mathrm{ZIM} / 14 / 98$ & BTY2RS2 & KJ999925 \\
\hline & $\mathrm{SAR} / 2 / 10$ & PK1RS2 & KJ999913 \\
\hline & ZAM/2/93 & PK1RS3 & DQ009719 \\
\hline & $\mathrm{KNP} / 10 / 03$ & PK1RS2 & KJ999916 \\
\hline & $\mathrm{SAR} / 9 / 81$ & B1BHK4B1RS2 & DQ009715 \\
\hline & NAM/272/98 & PK2RS1 & KJ999921 \\
\hline \multirow[t]{12}{*}{ SAT3 } & $\mathrm{KNP} / 10 / 90$ & PK2RS2 & KF647849 \\
\hline & $\mathrm{KNP} / 14 / 96$ & PK1RS1 & MK415741 \\
\hline & SAR/1/06 & BHK5 BTY1 & MK415736 \\
\hline & $\mathrm{KNP} / 8 / 02$ & PK2 & MK415739 \\
\hline & BOT/6/98 & BTY1RS2 & MK415742 \\
\hline & $\mathrm{KNP} / 2 / 03$ & PK1RS1 & MK415738 \\
\hline & $\mathrm{KNP} / 1 / 03$ & PK1RS1 & MK415737 \\
\hline & SAR/14/01 & PK1RS2 & MK415740 \\
\hline & ZAM/5/93 & PK1RS4BHK6 & MK415744 \\
\hline & $\mathrm{ZIM} / 5 / 91$ & BTY1RS4 & MK415745 \\
\hline & KNP/6/08 & PK1RS1 & MK415735 \\
\hline & $\mathrm{ZIM} / 11 / 94$ & BTY2RS5 & MK415743 \\
\hline SAT2 & $\mathrm{ZIM} / 7 / 83$ & B1BHK5B2RS2 & DQ009726 \\
\hline \multirow[t]{2}{*}{ A } & $\mathrm{A} 22 / \mathrm{IRAQ}$ & B2/TBTY2BHK2RS2 & AY593764 \\
\hline & A24/CRUZEIRO & B6BHK2RS3BHK3 & AJ251476 \\
\hline
\end{tabular}

${ }^{\star} P K$, pig kidney cells; RS, Instituto Biologico Renal Suino-2 (IB-RS-2) cells; BTY, bovine thyroid cells; B, Bovine; BHK, baby hamster kidney cells.

milk powder (Elite) and incubated with the $N k u k u^{\circledR}$ library phage particles $\left(10^{12}-10^{13}\right.$ transducing particles). Exponentially growing Escherichia coli TG1 cells (Stratagene, USA) were infected with eluted phage-displayed scFvs that had bound to the specific viruses before plating on TYE plates (15 g/l agar, $8 \mathrm{~g} / \mathrm{l}$ $\mathrm{NaCl}, 10 \mathrm{~g} / \mathrm{l}$ tryptone, $5 \mathrm{~g} / \mathrm{l}$ yeast extract) supplemented with $2 \%$ $(\mathrm{w} / \mathrm{v})$ glucose and $100 \mu \mathrm{g} / \mathrm{ml}$ ampicillin. Subsequent to overnight incubation, the bacteria were collected and the phagemids rescued by the addition of $\mathrm{M} 13 \mathrm{KO} 7$ helper phage. Infected bacterial cells were incubated overnight in $2 \times$ TY medium (16 $\mathrm{g} / \mathrm{l}$ tryptone, $10 \mathrm{~g} / \mathrm{l}$ yeast extract, $5 \mathrm{~g} \mathrm{NaCl} / \mathrm{l})$ containing $100 \mu \mathrm{g} / \mathrm{ml}$ ampicillin and $25 \mu \mathrm{g} / \mathrm{ml}$ kanamycin. Phages displaying scFvs were precipitated from the cell-free culture supernatant with one-fifth of the original culture volume of $20 \%$ (w/v) PEG8000 in $\mathrm{NaCl}$ and were then suspended in $1 \times$ PBS for use in the next selection round. A total of three such selection rounds were performed. The input and output phages from each selection round was titered to monitor enrichment. The outputs of each consecutive selection round was tested in a polyclonal ELISA. Single clones from the third selection round was tested 
as soluble scFvs for specific binding to SAT1/KNP/196/91, SAT3/KNP/10/90, or A22.

\section{Polyclonal Phage ELISA}

van Wyngaardt et al. (36) and Opperman et al. (25) described the polyclonal phage ELISA. In short, SDG purified virus $(30 \mu \mathrm{g} / \mathrm{ml})$ of either SAT1/KNP/196/91, SAT3/KNP/10/90, or A22 was used to coat 96-well Maxisorp immunoplates $\left(\mathrm{Nunc}^{\circledR}\right)$ ) overnight at $4{ }^{\circ} \mathrm{C}$. To confirm the specificity of the phage-displayed scFvs to the respective viruses, $1 \times$ PBS containing $2 \%$ milk powder (Elite) was used as a blocking reagent and negative control. Bound PEGprecipitated phage-displayed scFvs, produced at each selection round, were detected with the MAb B62-FE2 (100 ng/ml, Progen Biotechnik) and horseradish peroxidase-conjugated polyclonal rabbit anti-mouse IgG (PO260, Dako). After a final wash

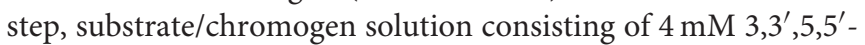
Tetramethylbenzidine (Sigma-Aldrich) in substrate buffer $(0.1 \mathrm{M}$ citric acid monohydrate, $0.1 \mathrm{M}$ tri-potassium citrate, $\mathrm{pH} 4.5$ ) and $0.015 \% \mathrm{H}_{2} \mathrm{O}_{2}$ was added for the colormetric reaction. Following 10 min incubation at room temperature, the color reaction was stopped with $1 \mathrm{M} \mathrm{H}_{2} \mathrm{SO}_{4}$ and the absorbance values were recorded at an absorbance of $450 \mathrm{~nm}\left(\mathrm{~A}_{450 \mathrm{~nm}}\right)$.

\section{Monoclonal Phage ELISA}

Following the third round of panning, monoclonal phage antibodies were screened by randomly selecting individual clones from the titration plates and inoculating it into a 96-well tissueculture plate (Nunc ${ }^{\circledR}$ ) containing 2 x TY medium supplemented with $100 \mu \mathrm{g} / \mathrm{ml}$ ampicillin and 2\% (w/v) glucose. The bacteria were grown overnight with shaking at $30^{\circ} \mathrm{C}$. Using a 96-well inoculation device (Sigma-Aldrich: Cat. No. R-2508), bacterial cells were transferred from the overnight plate to a second plate containing $150 \mu \mathrm{l}$ of fresh medium per well-followed by incubation for $2.5 \mathrm{~h}$ at $37^{\circ} \mathrm{C}$ with shaking. Subsequently, $50 \mu \mathrm{l}$ of medium that contained $2 \times 10^{9}$ of the M13K07 helper phage was added to each well and the plate incubated for $30 \mathrm{~min}$ at $37^{\circ} \mathrm{C}$ without shaking. Thereafter, plates were centrifuged at $600 \times \mathrm{g}$ for $10 \mathrm{~min}$, the supernatant fractions were removed and replaced with $150 \mu \mathrm{l}$ of $2 \times$ TY medium containing $100 \mu \mathrm{g} / \mathrm{ml}$ ampicillin and $25 \mu \mathrm{g} / \mathrm{ml}$ kanamycin prior to incubation overnight at $30^{\circ} \mathrm{C}$ with shaking. Following centrifugation at $600 \times \mathrm{g}$ for $10 \mathrm{~min}$ to pellet bacterial cells, the supernatant fractions, which contained the phage-displayed scFvs were removed and mixed 1:1 with $1 \times$ PBS containing $4 \%(\mathrm{w} / \mathrm{v})$ casein and $0.2 \%(\mathrm{v} / \mathrm{v})$ Tween-20 prior to undergoing ELISA testing as described for the polyclonal phage ELISA above.

\section{Monoclonal Soluble scFv ELISA}

The monoclonal soluble scFv ELISA has been described by van Wyngaardt et al. (36) and Opperman et al. (25). The method is similar to the monoclonal phage ELISA described above, except, instead of rescuing phages with the M13K07 helper phage, soluble scFvs were induced by adding $2 \times$ TY containing $100 \mu \mathrm{g} / \mathrm{ml}$ ampicillin and $3 \mathrm{mM}$ IPTG. The anti-c-Myc MAb 9E10, expressed from the murine hybridoma Mycl-9E10 (SigmaAldrich) and the polyclonal rabbit anti-mouse IgG conjugated to horseradish peroxidase (P0260; Dako) detected the secreted soluble scFvs. The ELISA colormetric reaction was performed as described above.

\section{DNA Sequencing and Sequence Analysis of Phage-Displayed scFvs}

Phagemid DNA for monoclonal scFv ELISA positive clones were sequenced [ABI PRISM ${ }^{\mathrm{TM}}$ Big Dye ${ }^{\mathrm{TM}}$ Terminator Cycling Ready Reaction Kit v.3.0 (Applied Biosystems)]. The clones were inoculated into $2 \mathrm{x}$ TY medium containing $100 \mu \mathrm{g} / \mathrm{ml}$ ampicillin and 20\% (w/v) glucose and phagemid DNA was isolated with a QIAprep ${ }^{\circledR}$ Spin Miniprep Kit (Qiagen) as per the manufacturer's instructions. The OP52 forward primer $\left(5^{\prime}\right.$ CCCTCATAGTTAGCGTAACG-3') and M13 reverse primer ( $5^{\prime}$ CAGGAAACAGCTATGAC- $3^{\prime}$ ), as well as the ABI PRISM ${ }^{\mathrm{TM}}$ Big Dye $^{\mathrm{TM}}$ Terminator Cycling Ready Reaction Kit v.3.0 (Applied Biosystems) was used to sequence the single clones (36). An ABI 3100 automated sequencer resolved the extension products and all sequences were edited, assembled and translated using BioEdit v.7.0.9 (45) and Sequencher v5.4.6 (Gene Codes Corporation, Ann Arbor, MI, USA) software.

\section{Large Scale Expression and Purification of Soluble scFvs}

Glycerol stocks $(150 \mu \mathrm{l})$ of selected phage clones were inoculated in $90 \mathrm{ml}$ of $2 \times \mathrm{TY}$ medium $(16 \mathrm{~g} / \mathrm{L}$ tryptone, $10 \mathrm{~g} / \mathrm{L}$ yeast extract, $5 \mathrm{~g} / \mathrm{L} \mathrm{NaCl}$ ) containing $100 \mu \mathrm{g} / \mathrm{ml}$ ampicillin and $2 \%$ $(\mathrm{w} / \mathrm{v})$ glucose and incubated overnight at $30{ }^{\circ} \mathrm{C}$ with shaking. A 1:10 dilution of the overnight culture was prepared in $800 \mathrm{ml}$ of fresh $2 \times$ TY medium containing $100 \mu \mathrm{g} / \mathrm{ml}$ ampicillin and $2 \%(\mathrm{w} / \mathrm{v})$ glucose and incubation, with shaking, continued for a further $8 \mathrm{~h}$ after which the bacterial cells were pelleted at 4,000 $\times \mathrm{g}$ for $30 \mathrm{~min}$. All traces of glucose-containing $2 \times \mathrm{TY}$ media was removed and the bacterial pellet resuspended in $1 \mathrm{~L}$ of $2 \times$ TY media containing $100 \mu \mathrm{g} / \mathrm{ml}$ ampicillin and $1 \mathrm{mM}$ IPTG and incubated overnight at $30^{\circ} \mathrm{C}$ with shaking. The expressed soluble $\mathrm{scFv}$ was harvested by pelleting the bacterial cells at $4,000 \times \mathrm{g}$ for $30 \mathrm{~min}$.

The bacterial pellets were resuspended in $50 \mathrm{ml}$ of TSA buffer (0.05 M Tris, $0.1 \mathrm{M} \mathrm{NaCl}, 0.02 \% \mathrm{NaN}_{3}, 0.02 \%$ sodium azide; $\mathrm{pH}$ $8.0)$ and treated with $0.01 \%(\mathrm{v} / \mathrm{v})$ of $100 \mathrm{mg} / \mathrm{ml}$ lysozyme for $30 \mathrm{~min}$ at $30^{\circ} \mathrm{C}$. Freshly prepared $200 \mathrm{mM}$ phenylmethylsulfonyl fluoride $[0.01 \%(\mathrm{v} / \mathrm{v})]$ in isopropanol was added to the bacterial suspension and the suspension mixed by inverting. The bacterial suspension was sonicated for $3 \mathrm{~min}$ (30 s pulses with $30 \mathrm{~s}$ pauses), where after, the bacterial pellet was collected by centrifugation at $15,000 \times \mathrm{g}$ for $30 \mathrm{~min}$ and the clear lysate filtered through 0.8 and $0.45 \mu \mathrm{m}$ filters, respectively. The anti-myc-Sepharose column coupled with $143 \mathrm{mg}$ of 9E10 Mab (prepared by Janine Frischmuth, the National Bioproducts Institute, Biotechnology division, Pinetown, South Africa) was washed with TSA buffer before the clear lysate (containing soluble scFvs) was loaded through the column via a peristaltic pump. The column was washed with TSA buffer until the spectrophotometer reading at absorbance $A_{280 n m}$ fell below 0.3. Soluble scFvs were eluted from the column with elution buffer $(0.1 \mathrm{M}$ glycine, $0.14 \mathrm{M}$ $\mathrm{NaCl}, \mathrm{pH}$ 2.2) and fractions collected. Peak fractions were pooled 
and the scFvs dialyzed (Sigma-Aldrich, dialysis tubing cellulose membrane, $10 \mathrm{~mm}$ flat width), for $48 \mathrm{~h}$ at $4^{\circ} \mathrm{C}$, in $2 \mathrm{~L} \mathrm{PBS} \mathrm{pH} \mathrm{7.4.}$

\section{Binding Specificity of Soluble scFvs}

The specificity of the soluble scFvs was tested with an ELISA essentially performed as described for the monoclonal phage ELISA. ELISA plates were coated in duplicate with $30 \mu \mathrm{g} / \mathrm{ml}$ of purified SAT1/KNP/196/91, SAT2/ZIM/7/83, SAT3/KNP/10/90, A22, or A24 viruses as well as with BHK-21 cell extract, 2\% $(\mathrm{w} / \mathrm{v})$ sucrose and $1 \times \mathrm{PBS}$ containing $2 \%(\mathrm{w} / \mathrm{v})$ milk powder as negative controls.

\section{Neutralization Assays and Generation of Virus Escape Mutants}

IB-RS-2 cells were used to determine the $50 \%$ tissue culture infective dose (TCID $\left.{ }_{50}\right)$ of A22 (OIE Terrestrial Manual, 2018). Similarly, BHK-21 cells were used to determine the virus titers for SAT1/KNP/196/91 and SAT3/KNP/10/90. The resulting virus titers were used to calculate the dilutions subsequently used in the virus neutralization test (VNT).

Virus dilutions containing $\sim 500,50$, and 5 infectious particles were prepared in the appropriate cell medium (RPMI for IB-RS-2 cells and GMEM for BHK-21 cells) and were applied in triplicate wells across a microtiter plate and diluted two-fold down the plate. Virus was incubated for $1 \mathrm{~h}$ at $37^{\circ} \mathrm{C}$ in an atmosphere of $5 \% \mathrm{CO}_{2}$ after purified scFvs at a concentration between 0.03 and $0.23 \mathrm{mg} / \mathrm{ml}$ were added neat to appropriate wells. A control plate without soluble scFvs was included. BHK-21 and IB-RS2 cells supplemented with $1 \%(\mathrm{v} / \mathrm{v})$ FCS and antibiotics (virus growth medium, VGM), with a cell count of $0.3 \times 10^{6}$ cells $/ \mathrm{ml}$ for both cell lines, were subsequently added to the respective microtiter plates. Incubation of microtiter plates then occurred for $72 \mathrm{~h}$ at $37^{\circ} \mathrm{C}$ and fixation and staining with a methylene blue-formaldehyde stain to allow for inspection of the cytopathic effect, which was scored as a measure of neutralization.

To generate virus neutralization escape mutants, the viruses (SAT1/KNP/196/91, SAT3/KNP/10/90, and A22) were passaged under scFv pressure as described by Crowther et al. (19) and Opperman et al. (25). Equal volumes of ca. 25 infectious virus particles were diluted two-fold in GMEM or RPMI medium on a microtiter plate before being mixed with an equal volume of the respective purified $\mathrm{scFv}$ (neat), followed by 30 min incubation at $37^{\circ} \mathrm{C}$. The virus-scFv complexes were added to either BHK21 or IB-RS- 2 monolayer cells and incubated for $1 \mathrm{~h}$ at $37^{\circ} \mathrm{C}$. Following incubation, the virus-scFv complexes were removed. Monolayers were washed twice with GMEM or RPMI (SigmaAldrich) medium before VGM containing a 1:50 dilution of purified scFvs at a concentration between 0.6 and $4.6 \mu \mathrm{g} / \mathrm{ml}$ were added. All scFvs were tested. Each virus was subjected to four consecutive passages under $\mathrm{scFv}$ pressure.

\section{Characterization of Virus Escape Mutants}

Virus escape mutants were then characterized by sequencing the Leader- P1-2A coding region (ca. $3 \mathrm{~kb}$ ) of the virus genome. RNA extraction was performed using the QIAmp viral RNA kit (Qiagen). cDNA was synthesized with SuperScript III first strand synthesis kit (Invitrogen), using the genome specific primer WDA 5'-GAAGGGCCCAGGGTTGGACTC-3'.

The Leader-P1-2A coding region of the escape viruses were amplified using the Expand Long Template PCR System (Roche) and forward primer NCR1 5'TACCAAGCGACACTCGGGATCT- $3^{\prime}$ and reverse primer WDA 5'-GAAGGGCCCAGGGTTGGACTC-3'. Briefly, each $50 \mu \mathrm{l}$ PCR reaction mixture consisted of $3 \mu \mathrm{l}$ of the first strand cDNA reaction mixture, $0.3 \mu \mathrm{M}$ of each oligonucleotide, $2.5 \mathrm{U}$ of Expand Long Template DNA polymerase, $1 \times$ Expand buffer, $0.75 \mathrm{mM} \mathrm{MgCl}$ and $2 \mu \mathrm{M}$ of each dNTP. Using a thermocycler (GeneAmp 9700, Applied Biosystems) after initial denaturation at $94^{\circ} \mathrm{C}$ of $2 \mathrm{~min}$, the reactions were subjected to 35 cycles of $94^{\circ} \mathrm{C}$ for $20 \mathrm{~s}, 55^{\circ} \mathrm{C}$ for $20 \mathrm{~s}$ and $68^{\circ} \mathrm{C}$ for $4 \mathrm{~min}$ with a final cycle of $68^{\circ} \mathrm{C}$ for $7 \mathrm{~min}$ to complete the synthesis of all strands.

To determine the nucleotide sequence of the gel-purified amplicons, $0.16 \mu \mathrm{M}$ of the appropriate oligonucleotide (Table 2) and the ABI PRISM Big Dye Terminator Cycling Ready Reaction kit v3.0 (Applied Biosystems) was utilized. The extension products were resolved on an ABI PRISM ${ }^{\mathrm{TM}} 3100$ automated sequencer (Applied Biosystems) and sequences analyzed using the BioEdit v.7.0.9 (45) and Sequencher v5.4.6 (Gene Codes Corporation, Ann Arbor, MI, USA) software of the ca. 2.2-kb P1-coding region.

\section{Investigation of the SAT1 and SAT3 Soluble scFvs as Capturing Antibodies in an Indirect ELISA}

The SAT1 and SAT3 soluble scFvs were tested in an indirect ELISA against a panel of viruses (Table 1) to determine whether it can be used as capturing antibodies in routine testing of suspected FMDV cases. The PEG concentrated viruses were titrated in a liquid phase blocking ELISA [LPBE; (46)] to determine the optimal dilution where an absorbance value at $450 \mathrm{~nm}\left(\mathrm{~A}_{450 \mathrm{~nm}}\right)$ of ca. one was obtained. The virus dilution of 1:8 was chosen for the scFv ELISA as this was the highest dilution where an $\mathrm{A}_{450 \mathrm{~nm}} \sim 1$ (with standard deviation of 0.25 , observed after the ELISA colorimetric reaction) was obtained for the viruses tested. The purified, neat scFvs (SAT1scFv1 0.03 $\mathrm{mg} / \mathrm{ml}$, SAT3scFv1 $0.039 \mathrm{mg} / \mathrm{ml}$, and SAT3scFv2 $0.09 \mathrm{mg} / \mathrm{ml}$ ) were used to coat 96-well Maxisorp immunoplates ( $\mathrm{Nunc}^{\circledR}$ ) overnight at $4{ }^{\circ} \mathrm{C}$, following which, ELISA plates were washed

TABLE 2 | Oligonucleotides used for sequencing the virus escape mutants.

\begin{tabular}{ll}
\hline Oligonucleotide & *'Sequence \\
\hline Linternal & 5'-GWTACGTCGATGARCC-3' \\
NCR1 & 5'-TACCAAGCGACACTCGGGATCT-3' \\
WDA & 5'-GAAGGGCCCAGGGTTGGACTC-3' \\
SEQ 16 & 5'-GTGGAACAAGCAGAGAGG T-3' \\
SEQ 18 & 5'-CAACTGCAACGTCCTTCTC-3'
\end{tabular}

*In selected oligonucleotides, the abbreviation represents ambiguities i.e., $W=A$ or $T, R=A$ or $G$. 
four times with wash buffer $[1 \times$ PBS containing $0.05 \%(\mathrm{v} / \mathrm{v})$ Tween 20]. As a blocking reagent and negative control, 2\% milk powder in $1 \times$ PBS was used. Diluted PEG concentrated virus $(1: 8)$ was added to the $s c F v$ coated plates and incubated for $1 \mathrm{~h}$ at $37^{\circ} \mathrm{C}$. Following incubation and washing, serotype specific guinea pig antiserum (typing/detecting antibody, ARCOVR-VDD) was added (working dilution for SAT1 and SAT2 was 1:100 and SAT3 whilst for A it was 1:50) and plates were again incubated for $1 \mathrm{~h}$ at $37^{\circ} \mathrm{C}$ and then washed. The conjugate (rabbit anti-guinea pig IgG conjugated to horseradish peroxidase, Sigma-Aldrich) diluted at 1:80, was added to respective microtiter plate wells, followed by $1 \mathrm{~h}$ at $37^{\circ} \mathrm{C}$ incubation and washing. The ELISA colorimetric reaction followed using substrate-chromogen solution, consisting of $4 \mathrm{mM} 3,3^{\prime}, 5,5^{\prime}$ Tetramethylbenzidine (Sigma-Aldrich) in substrate buffer $(0.1 \mathrm{M}$ citric acid monohydrate, $0.1 \mathrm{M}$, disodium hydrogen phosphate; $\mathrm{pH}$ 4.5) $0.015 \%(\mathrm{v} / \mathrm{v}) \mathrm{H}_{2} \mathrm{O}_{2}$. Following $10 \mathrm{~min}$ incubation at room temperature, the colorimetric reaction was stopped with $1.25 \mathrm{M} \mathrm{H}_{2} \mathrm{SO}_{4}$. The $\mathrm{A}_{450 \mathrm{~nm}}$ was determined using a Labsystems Multiskan Plus photometer (Thermo Fisher Scientific). The samples were tested in duplicate wells and the absorbance calculated as an average of the two values for each sample. A positive ELISA result was calculated as two-fold the $A_{450 \mathrm{~nm}}$ value of the average negative control.

\section{Investigation of the SAT1 and SAT3 Soluble scFvs as Detecting Antibodies in an Indirect ELISA}

The SAT1- and SAT3-specific soluble scFvs from this study were further investigated for their suitability as a detecting antibody for the FMDV antigen in an ELISA format. 96well ELISA plates $\left(\right.$ Nunc $\left.^{\circledR}\right)$ were coated with either SAT1, SAT2, SAT3, or A specific rabbit antiserum. A 1:8 dilution of PEG concentrated viruses (Table 1) were added to the coated 96-well Maxisorp immunoplates ( $\mathrm{Nunc}^{\circledR}$ ) and incubated for $1 \mathrm{~h}$ at $37^{\circ} \mathrm{C}$. Following a wash step with wash buffer i.e., $1 \times$ PBS containing $0.05 \%(\mathrm{v} / \mathrm{v})$ Tween 20 , undiluted scFvs (SAT1scFv1 $0.03 \mathrm{mg} / \mathrm{ml}$, SAT3scFv1 $0.039 \mathrm{mg} / \mathrm{ml}$, and SAT3scFv2 $0.09 \mathrm{mg} / \mathrm{ml}$ ) were added and ELISA plates incubated for $1 \mathrm{~h}$ at $37^{\circ} \mathrm{C}$. Microtiter plates were washed and the soluble scFvs that bound to the FMD antigen were detected with the anti-c-Myc antibody clone 9E10 (Sigma-Aldrich) and 1: 1,000 dilution of horseradish peroxidase (HRP)-conjugated polyclonal rabbit anti-mouse IgG (PO260; Dako). The negative control contained $2 \%$ milk powder (Elite) in $1 \times$ PBS instead of the scFvs. The substrate/chromogen solution and $\mathrm{A}_{450 \mathrm{~nm}}$ determination was performed as described above and a positive $\mathrm{A}_{450 \mathrm{~nm}}$ value was considered greater-than or equal to twofold the average negative control value. The test samples were tested in duplicate and the absorbance calculated as an average of the two values for each test sample. The LPBE was adapted and essentially carried out in conjunction as a comparison of performance of the $s c F v$ detecting ELISA and was undertaken as described in the Office International des Epizooties (46).

\section{RESULTS}

\section{Selection and Identification of Phage-Displayed scFvs Against FMDV SAT1/KNP/196/91, SAT3/KNP/10/90, and A22}

The large semi-synthetic naïve $N k u k u^{\circledR}$ phage display library based on chicken immunoglobulin genes, was panned by exposing the recombinant antibody repertoire to SDG purified virions of the FMD SAT1/KNP/196/91, SAT3/KNP/10/90, and A22 viruses. After three consecutive biopanning rounds, polyclonal phage displayed scFvs were tested in a polyclonal ELISA to evaluate enrichment (Figure 1) for each of the three biopannings to the specific viruses. The phage outputs from the three consecutive selection rounds were tested and an aliquot of the library prior to panning was included as a non-enriched control (Figure 1). Output phages from selection round three resulted in $\mathrm{A}_{450 \mathrm{~nm}}$ of $1.05,1.35$, and 2.48 for SAT1/KNP/196/91, SAT3/KNP/10/90, and A22, respectively (Figures 1A-C). The $N k u k u^{\circledR}$ non-enriched control (selection round 0) produced $\mathrm{A}_{450 \mathrm{~nm}}$ results of $0.13,0.10$, and 0.06 for SAT1/KNP/196/91, SAT3/KNP/10/90, and A22, respectively. An increase of at least eight-fold in the absorbance values after three pannings compared to the absorbance of a pre-panning aliquot of the $N k u k u^{\circledR}$ library proved enrichment for phage displayed antibodies for all three FMD viruses (Figures 1A-C).

Phage displayed scFvs specific for FMDV were identified after a helper phage rescue of single bacterial colonies from the third round of panning and tested in ELISA. Both the phage displayed and soluble $s c F v$ formats were tested and the results are summarized in Table 3. A total of 94 clones each for SAT1/KNP/196/91 and SAT3/KNP/10/90 and 188 clones for A22 were screened. Twenty clones expressed phage-displayed scFvs specific to SAT1/KNP/196/91 with ELISA signals more than two-fold greater than that of the negative control. Furthermore, of these, seven clones secreted soluble scFvs that bound to SAT1/KNP/196/91. Sequencing of the seven clones revealed one unique binder for SAT1/KNP/196/91, designated SAT1scFv1 (Table 4), which had seven identical clones. Analysis of the 94 clones for SAT3/KNP/10/90 revealed three clones expressing phage-displayed scFvs specific to $\mathrm{SAT} 3 / \mathrm{KNP} / 10 / 90$, all of which secreted soluble scFvs that bound to SAT3/KNP/10/90. Sequencing of these clones indicated two unique binders designated SAT3scFv1 and SAT3scFv2 (Table 4). In addition, of the 188 clones for A22, 25 clones expressed phage-displayed scFvs specific to A22, whilst 9 clones secreted soluble scFvs that bound to A22 and sequencing revealed nine unique binders for A22 designated A22scFv1 to A22scFv9 (Table 4). Interestingly, sequencing results revealed that SAT3scFv2 and A22scFv6 had an identical sequence in all three of the CDR's for the heavy and light chains and are essentially the same binder (Table 4). However, it must be noted that these biopannings were executed independently of each other and at different times and thus the possibility of cross-contamination is ruled out. The result inferred that the SAT3scFv2 and A22scFv6 binders recognize a conserved amino acid (aa) motif on 


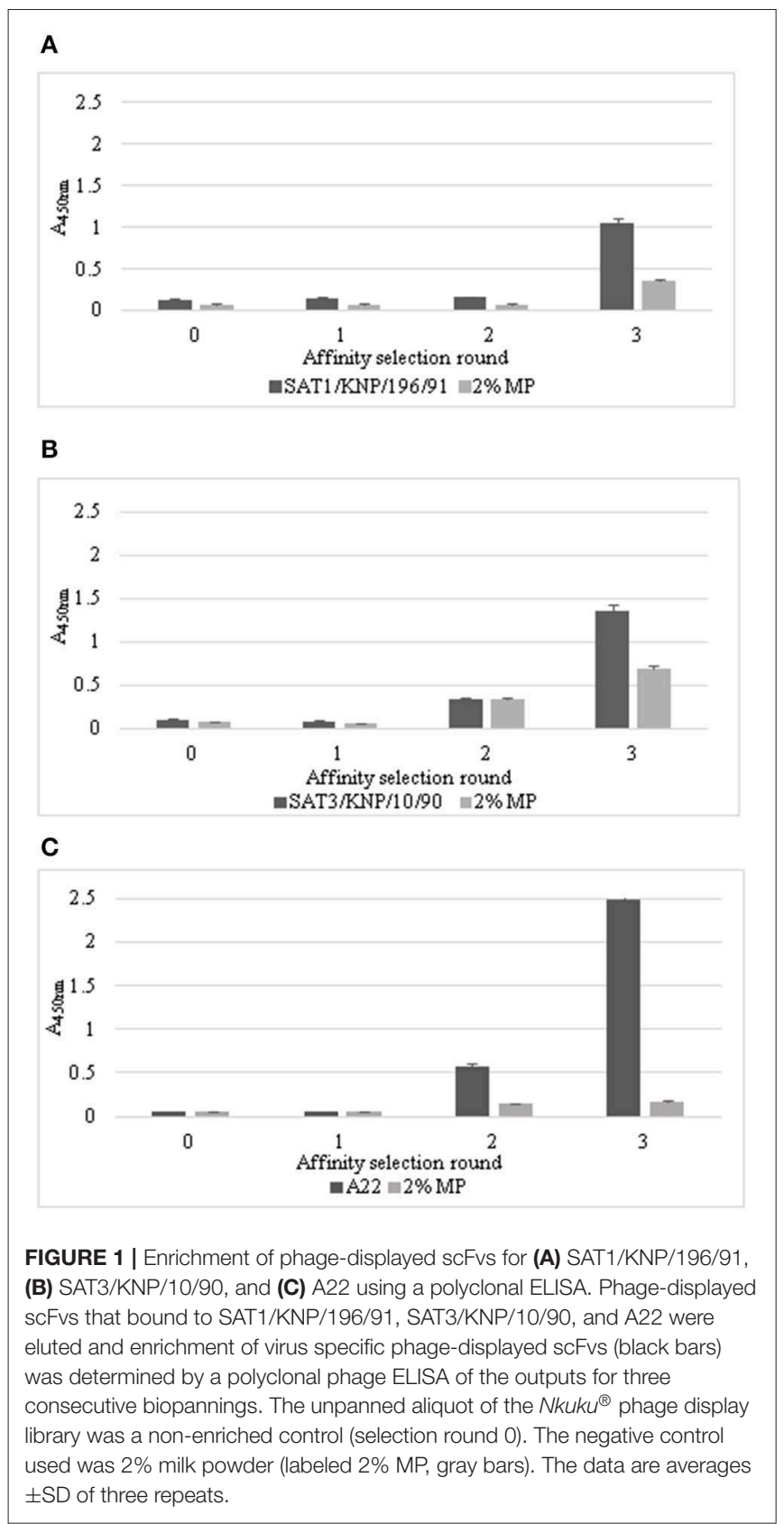

both SAT3/KNP/10/90 and A22 viruses. The soluble scFvs were subsequently successfully purified by means of affinity chromatography and further characterized.

\section{Binding Specificity of Soluble scFvs to FMDV}

The specificity of the virus-specific soluble scFvs were determined by measuring their ability to bind to purified, complete $146 \mathrm{~S}$ virions of viruses from serotypes A, SAT1, SAT2, and SAT3 in an ELISA. Negative controls were BHK-21 cell extract, $2 \%$ sucrose, and $2 \%$ milk powder (Figure 2). SAT1scFv1 phage-displayed binder cross-reacted with A22, SAT2/ZIM/7/83,
TABLE 3 | Screening for ScFvs following three rounds of biopanning.

\begin{tabular}{lcccc}
\hline FMD serotype & $\begin{array}{c}\text { Number of } \\
\text { clones } \\
\text { tested }\end{array}$ & $\begin{array}{c}\text { Phage } \\
\text { binders }\end{array}$ & $\begin{array}{c}\text { Soluble scFv } \\
\text { binders }\end{array}$ & $\begin{array}{c}\text { Unique } \\
\text { sequences/ } \\
\text { binders }\end{array}$ \\
\hline SAT1/KNP/196/91 & 94 & 20 & 7 & 1 \\
SAT3/KNP/10/90 & 94 & 3 & 3 & 2 \\
A22 & 188 & 25 & 9 & 9
\end{tabular}

and SAT3/KNP/10/90, however, the soluble $\mathrm{scFv}$ format did not exhibit any cross-reactivity (Figure 2). SAT3scFv1 phagedisplayed and soluble scFv cross-reacted with A22 and SAT1/KNP/196/91 whilst there was borderline cross-reactivity with SAT2/ZIM/7/83 observed for the phage-displayed scFv (Figure 2). The amino acid sequence of the heavy and light chain complementary determining regions (CDRs) of SAT3scFv2 and A22scFv6 are identical and the cross-reactivity between SAT3scFv2 and A22 as well as A22scFv6 and SAT3/KNP/10/90 was observed with both the phage-displayed and soluble scFv (Figure 2). SAT3scFv2 phage-displayed scFv also cross-reacted with SAT1/KNP/196/91, whereas the soluble scFv did not crossreact (Figure 2). A22scFv5 soluble scFv showed cross-reactivity to A24 virus and for the phage-displayed $\mathrm{scFv}$, borderline cross-reactivity was observed (Figure 2). There was no crossreactivity observed with the $\mathrm{A} 22 \mathrm{scFv} 1, \mathrm{~A} 22 \mathrm{scFv} 2, \mathrm{~A} 22 \mathrm{scFv} 3$, A22scFv4, A22scFv7, A22scFv8, and A22scFv9 binders with SAT1/KNP/196/91, SAT2/ZIM/7/83, SAT3/KNP/10/90, or A24 viruses. No cross-reactivity was observed with the reagents used for virus propagation and purification. The specificity investigations of the scFvs showed that the phage-displayed scFvs exhibited more prominent cross-reactivity when compared to the soluble scFvs. Due to this, further investigations for this study was continued with the soluble scFvs.

\section{Neutralization and Escape Mutant Investigations of the Identified scFvs}

The ability of the soluble scFv's against SAT1, SAT3, and A22 to neutralize the SAT1/KNP/196/91, SAT3/KNP/10/90, or A22 viruses, respectively, in vitro was investigated. The SAT1scFv1 was unable to neutralize FMDV SAT1/KNP/196/91. Similarly, SAT3scFv1 and SAT3scFv2 binders were unable to neutralize the SAT3/KNP/10/90 virus. Additionally, A22scFv6, being essentially the same binder as SAT3scFv2, was unable to neutralize A22 virus in vitro. Nonetheless, three of the nine A22 soluble scFv binders, i.e., A22scFv1 (0.16 mg/ml), A22scFv2 $(0.23 \mathrm{mg} / \mathrm{ml})$, and A22scFv8 $(0.18 \mathrm{mg} / \mathrm{ml})$, were able to neutralize A22 in vitro. The neutralization titers $\left(\right.$ TCID $\left._{50}\right)$ are indicated in Table 5.

FMDV A22 was serially passaged in the presence of soluble A22scFv1, A22scFv2, and A22scFv8 to select viruses from the A22 quasispecies population that escape neutralization by the soluble scFvs. Thus, the A22 viruses that escaped neutralization by soluble scFvs A22scFv1, A22scFv2, and A22scFv8 were designated $s c F v$ resistant virus (SRV) 1, 2, and 3, respectively. Following four consecutive passages under scFv pressure, the P1 nucleotide, and aa sequences were determined for SRV1, 
TABLE 4 | Amino acid sequence alignment of the complementary determining regions (CDR) of the heavy and light chains of the SAT1/KNP/196/91, SAT3/KNP/10/90, and A22-specific soluble scFvs panned from the $N k u k u^{\circledR}$ library.

scFv

Heavy Chain

Complementary determining region

\begin{tabular}{|c|c|c|c|}
\hline & CDR1 & CDR2 & CDR3 \\
\hline SAT1scFv1 & SSHGMF & EITN--TGSYAAYGAAV & CAKSSYECTSSCWGNTGWID \\
\hline SAT3scFv1 & SSNGMA & AISSRD-GSGTGYGSAV & CAKPVKGMY $----------I D$ \\
\hline SAT3scFv2 & SSFNMG & AINND--GGGTAYGSAV & CAKSVDDSWNV_-----DSID \\
\hline A22scFv1 & SSYSMQ & GIGS--DGSDTAYGAAV & CTKCGYGGS-GYCWYAGDID \\
\hline A22scFv2 & SSYEMQ & GIEN--DGSNPNYGAAV & CAKSAYGGSWGGYIPTDSID \\
\hline A22scFv3 & SDYAMG & GIGTSADGSSTAYGAAV & CTRTGAAE----------DID \\
\hline A22scFv4 & SSHGMG & SISR--DSSYTDYGPAV & CTKSAGPYVNGDN-----ID \\
\hline A22scFv5 & SDYGMS & EITND--DSWTGYGAAV & CAKNDYYSLF---------ID \\
\hline A22scFv6 & SSFNMG & AINND--GGGTAYGSAV & CAKSVDDSWNV_-----DSID \\
\hline A22scFv7 & SSYGMG & GIEN--DGRYTGYGSAV & CAKDIYG-VGGGAFGADTID \\
\hline A22scFv8 & SSYSMQ & GIGS--DGSDTAYGAAV & CTKCGYGGS-GYCWYAGDID \\
\hline A22scFv9 & SSYPMG & AISN--DGSYTGYGAAV & CAKDAYSYTTTGGWYVDEID \\
\hline
\end{tabular}

Light chain

Complementary determining region

\begin{tabular}{lll}
\hline CDR1 & CDR2 & CDR3 \\
SGDSSG----YGYG & YNNNKRPS & GTED-GITDAGI \\
SGGTYYA------- & YDNTNRPS & GAYDSS-TYAGl \\
SGGGSYAGS-YYYG & YDNTKRPS & GSYDSS---GGl \\
SGGGNE------YG & YWNDKRPS & GSYDSSA---Gl \\
SGG-SSS----YYG & YDNTNRPS & GSFDSSTV-Gl \\
SGG-SSS----YYG & YANTNRPS & GSSDSTY--VGl \\
SGGGRYAGNYYG & YSNNQRPS & GSADSNSTDGVT \\
SG--DSN--YYGYS & YDNDKRPS & GSADSSA---VI \\
SGGGSYAGS-YYYG & YDNTKRPS & GSYDSS---GGl \\
SGG-SYS-----YG & YDNTNRPS & GSIDSSY-V-Gl \\
SGGGS------YYG & YSNNQRPS & GSYDNSA---Gl \\
SGGGS------YYG & YDNTNRPS & GGIDSTD---AA
\end{tabular}

\begin{tabular}{|c|c|c|c|c|c|c|c|c|c|c|}
\hline & \multicolumn{5}{|c|}{ Phage-dis played scFv } & \multicolumn{5}{|c|}{ SolublescFv } \\
\hline & SATlscFv & SAT3sAFv & SAT3SAFv & $\mathrm{A} 22 \mathrm{scFv}$ & $\mathrm{A} 22 \mathrm{scFv}$ & SATlscFv & SAT3s $\mathrm{dFV}$ & SAT3s $\mathrm{FF}$ & $\mathrm{A} 22 \mathrm{scFv}$ & $\mathrm{A} 22 \mathrm{scFv}$ \\
\hline & 1 & 1 & 2 & 5 & 6 & 1 & 1 & 2 & 5 & 6 \\
\hline SAT1/KNP/196/91 & 1,48 & 0,89 & 0,61 & 0,10 & 0,28 & 1,00 & 0,51 & 0,20 & 0,15 & 0,21 \\
\hline SAT3/KNP/109O & 0,82 & 0,85 & 1,89 & 0,12 & 0,91 & 0,16 & 0,59 & 1,15 & 0,10 & 1,02 \\
\hline A 22 & 0,71 & 1,12 & 1,96 & 0,87 & 1,09 & 0,12 & 1,12 & 0,74 & 2,44 & 0,69 \\
\hline A24 & ND & ND & 0,18 & 0,29 & 0,12 & ND & $\mathrm{ND}$ & 0,14 & 1,92 & 0,16 \\
\hline $2 \%$ milk powder & 0,09 & 0,09 & 0,12 & 0,19 & 0,15 & 0,10 & 0,14 & 0,09 & 0,11 & 0,10 \\
\hline $\begin{array}{l}\text { FIGURE } 2 \text { | Heat map } \\
\text { SAT3scFv2, A22scFv5, } \\
\text { viruses or reagents (dat } \\
\text { SAT3/KNP/10/90 SDG } \\
\text { soluble scFv absorband }\end{array}$ & oresenting & a nesti & $\begin{array}{l}\text { HK-21 cell ex } \\
\text { result. }\end{array}$ & tract, $2 \%$ & ucrose, and & wder (MP) & n ELIS & hal two-fold & & $\begin{array}{l}\text { scFv1, } \\
\text { ny of the oth } \\
\text { M/7/83, and } \\
\text { milk powde }\end{array}$ \\
\hline
\end{tabular}

TABLE 5 | The 50\% tissue culture infectious dose (TCID 50 ) of A22 when neutralized by the A22 scFvs.

\begin{tabular}{lc}
\hline $\mathbf{s c F v} *$ & Neutralization titer $\left(\operatorname{TCID}_{\mathbf{5 0}} / \mathbf{5 0} \mu \mathrm{l}\right)$ \\
\hline A22scFv1 & 0.5 \\
A22scFv2 & 0.63 \\
A22scFv8 & 0.63
\end{tabular}

*Titer of A22 (without scFvs) was 1.25 TCID $50 / 50 \mu l$.

SRV2, and SRV3. Comparative analysis of the aa sequences of the SRVs compared to the parental A22 sequence indicated that SRV1 exhibited one aa substitution i.e., from a non-polar proline (Pro) to a polar serine (Ser) change at VP1 aa position 149 i.e., RGD+3 (Pro149 $\rightarrow$ Ser) (Figure 3). Interestingly SRV2 had no aa changes occurring in the P1 region, but SRV3 exhibited a single aa substitution of a leucine (Leu) to a phenylalanine (Phe) at position 150 of VP1 i.e., RGD+4 (Leu150 $\rightarrow$ Phe) (Figure 3). The aa substitutions for SRV1 and SRV3 occurred in the surface exposed and structurally flexible VP1 $\beta$ G- $\beta$ H loop, downstream of the RGD sequence.

The A22 virus was neutralized by three soluble scFvs and SRVs for A22, which showed a potential binding site for two of the scFvs in the GH-loop of the VP1 protein. The three CDRs of the H-chain of A22scFv1 and A22scFv8 are identical while the L-chain of A22scFv1 and A22scFv8 displayed different sequences (Table 4). Soluble scFvs for SAT1/KNP/196/91 and SAT3/KNP/10/90 viruses did not neutralize the respective viruses. Thus, the SAT1 and SAT3 scFvs were investigated for its potential use as diagnostic reagents in an ELISA.

\section{SAT Virus-Specific scFvs as a FMDV Capturing Antibody in a Sandwich ELISA}

To determine whether the SAT1 and SAT3 soluble scFv's retain the correct conformation to act as capturing reagents in a diagnostic sandwich ELISA, the soluble scFvs were coated 
A

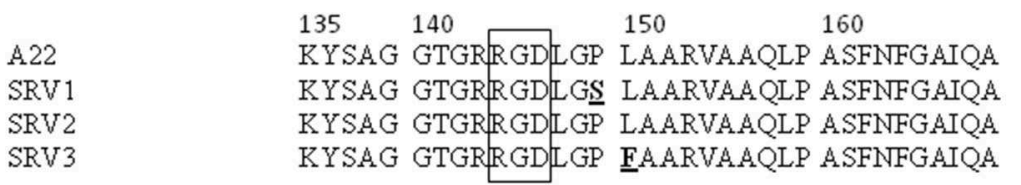
GH-loop

B

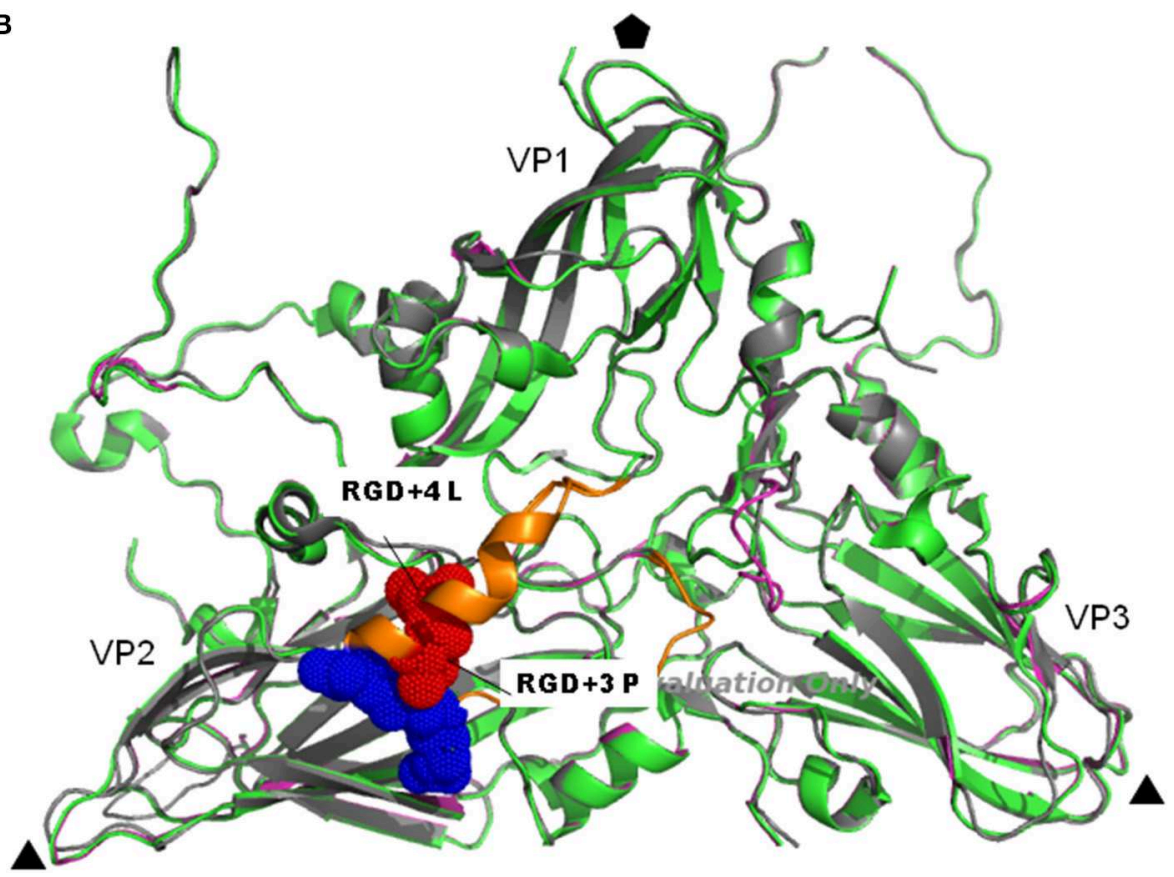

FIGURE 3 | (A) The A22 virus escape mutant substitutions are indicated in an aa alignment of the VP1 GH-loop of A22. The proline to serine (Pro149 $\rightarrow$ Ser) substitution at position 149 of VP1 for SRV1 and a leucine to a phenylalanine (Leu150 $\rightarrow$ Phe) substitution at position 150 of VP1 for SRV3 is shown in bold and underlined. The RGD motif is blocked. (B) The substitutions are shown as red dots on a cartoon model of the FMDV capsid proteins in a crystallographic protomer. The inferred 3-D structural model was rendered by Pymol v 1.8 (DeLano Scientific LLC). The VP1 GH-loop is absent from the A22 complete (PDB: 4GH4) and empty capsid (PDB: 5D8A) structures due to an instable loop conformation. However, the serotype O capsid structure (PDB: 1FOD) was reported with a VP1 GH-loop (47). The serotype A complete and empty capsid protomers (colored in green and magenta) were superimposed on the O protomer (in gray), showing the position of the VP1 GH-loop in orange and the receptor-binding RGD sequence as blue dots. The three-fold axis is depicted by the black triangles and the five-fold axis of the capsid by the black pentagon. The positions of the outer-capsid proteins, VP1, VP2, and VP3 are indicated.

directly onto maxisorp immunoplates. The antigen-binding activity of the immobilized soluble SATscFv1 was tested against a panel of PEG concentrated SAT1 $(n=11)$ viruses whilst soluble SAT3scFv1 and SAT3scFv2 was tested against a panel of SAT3 ( $n$ $=12$ ) viruses (Table $\mathbf{1}$ ).

The results revealed that soluble SAT1scFv1 successfully captured the panel of SAT1 viruses tested as ELISA signals of $\mathrm{A}_{450 \mathrm{~nm}} \geq 0.48$ and $\leq 1.68$ were obtained (Figure 4A). Weak positive $\mathrm{A}_{450 \mathrm{~nm}}$ of $>0.4,<0.9$ was observed when SAT1scFv1 captured SAT1/SAR/9/81, SAT1/ZIM/14/98, SAT1/KNP/10/03, SAT/NAM/272/98, and SAT1/SAR/2/10 (Figure 4A). Additionally, strong positive signals $A_{450 \mathrm{~nm}}>1$, $<1.68$ for SAT1/KNP/3/03, SAT1/SAR/9/03, SAT1/ZAM/2/93, SAT1/SAR/33/00, SAT1/BOT/1/06, and SAT1/KNP/196/91 were observed when SAT1scFv1 was the capturing reagent (Figure 4A).
SAT3scFv1 and SAT3scFv2 soluble scFvs did not react efficiently with the SAT3 viruses when applied as a capturing reagent and displayed $A_{450 n m}$ signals not significantly higher than the negative controls. Weak positive results were obtained for SAT3scFv1 with SAT3/KNP/6/08 ( $\mathrm{A}_{450 \mathrm{~nm}}$ 0.6) (Figure 4B). SAT3scFv1 showed similar reactivity to SAT3/BOT/6/98 $\left(\mathrm{A}_{450 \mathrm{~nm}}\right.$ $0.31)$ SAT3/KNP/1/03 (A $450 \mathrm{~nm} 0.31$ ), and SAT3/ZIM/11/94 $\left(\mathrm{A}_{450 \mathrm{~nm}} 0.40\right)$ viruses indicating this $\mathrm{scFv}$ may recognize the same epitope on the virion for these viruses (Figure 4B). Additionally, absorbance values of both the SAT3 scFvs in the capturing ELISA against the virus used for the panning i.e., SAT3/KNP/10/90 was $<0.2$.

Overall, the ELISA results using the scFvs as capturing reagents indicate that the soluble $\mathrm{SAT} 1 \mathrm{scFv} 1$ was able to successfully bind to the polystyrene ELISA plate and react to viruses within the SAT1 serotype. The SAT3scFv1 and SAT3scFv2 


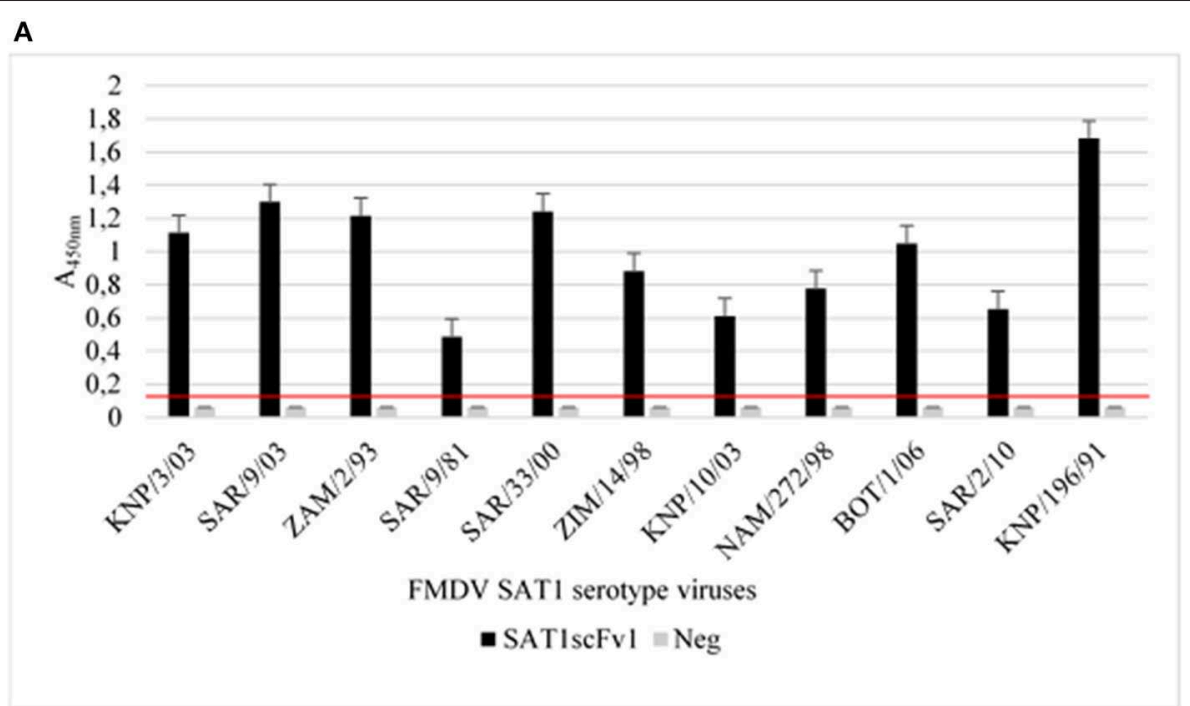

B

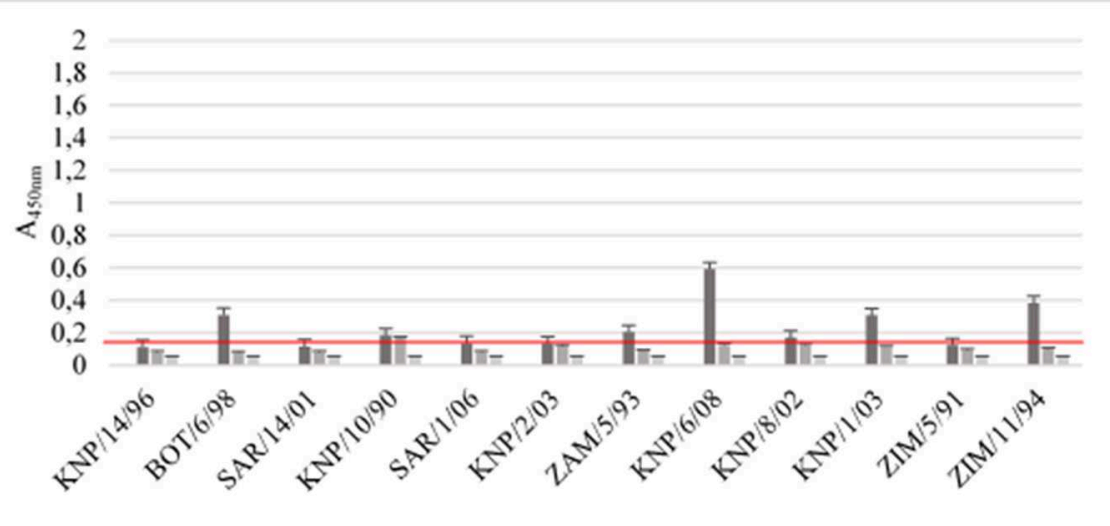

FMDV SAT3 serotype viruses

=SAT3scFv1 $\approx$ SAT3scFv2 $=$ Neg

FIGURE 4 | A sandwich ELISA with soluble scFvs as capturing antibodies. The SAT1scFv1 was tested with a panel of PEG concentrated SAT1 viruses (A) and SAT3scFv1 and SAT3scFv2 was tested with the SAT3 viruses (B). For the negative control (neg), $2 \%$ milk powder was included in the assays replacing the soluble scFvs coating the plate. The data are means \pm SD of two independent experiments. An ELISA signal more than two-fold that of the negative control A450nm was considered a positive result and the cut-off is indicated by a red line.

exhibited no or borderline reactivity with the SAT3 viruses tested. The low signals may be attributed to the conformational changes of the scFvs when binding to the ELISA plate. Furthermore, aa differences in the viral proteins may result in the variable ELISA signals observed.

\section{SAT Virus-Specific scFvs as a FMDV Detecting Antibody in an ELISA}

The soluble scFvs, SAT1scFv1, SAT3scFv1, and SAT3scFv2, were also applied as detecting antibodies in a sandwich ELISA. FMD virus was captured by polyclonal rabbit antiserum and the soluble scFvs was used to detect the $146 \mathrm{~S}$ virus particles using the panel in Table 1. The standard diagnostic sandwich ELISA used for antigen detection (46) was performed concurrently as a comparison of the scFv ELISA performance.

Results showed that the diagnostic antigen detection ELISA was able to detect all viruses tested and produced positive ELISA signals (Figures 5A,B). The ELISA assay using SAT1scFv1 as a detecting antibody revealed two characteristic reactivity profiles against the panel of SAT1 viruses, i.e., (i) $A_{450 \mathrm{~nm}}$ $>1.4$ was observed for SAT1/SAR/9/03, SAT1/KNP/196/91, and SAT1/NAM/272/98 viruses and (ii) $\mathrm{A}_{450 \mathrm{~nm}}$ absorbance values of $\geq 0.4, \leq 0.82$ for the remaining eight SAT1 viruses in the panel (Figure 5A).

The soluble SAT3scFv1 and SAT3scFv2 showed low absorbance signals for the SAT3 viruses tested (Figure 5B). 
A

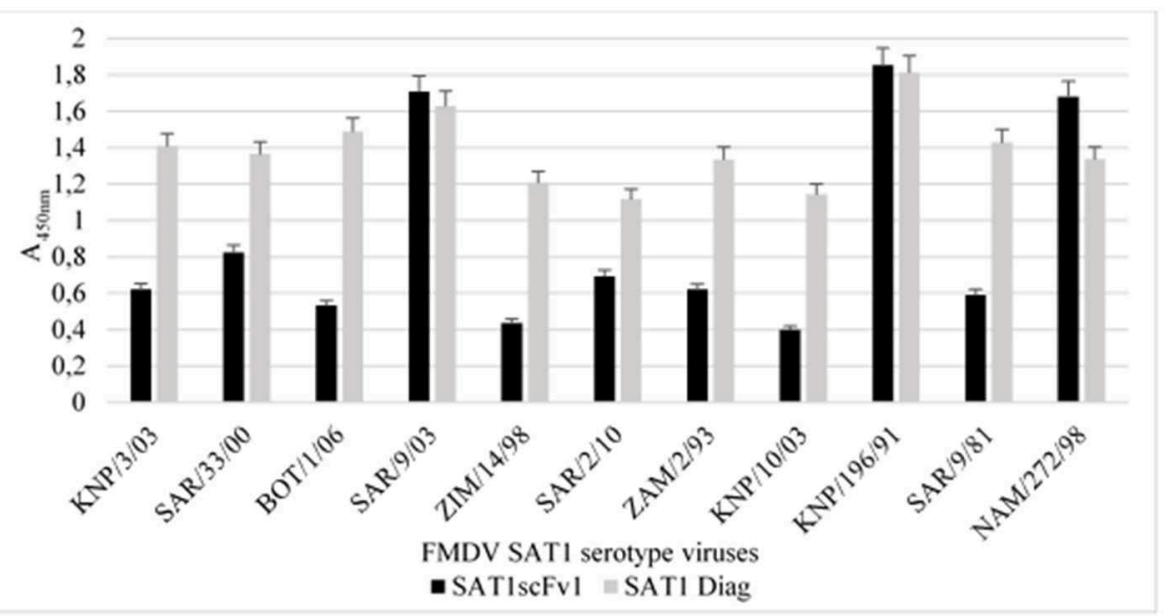

B

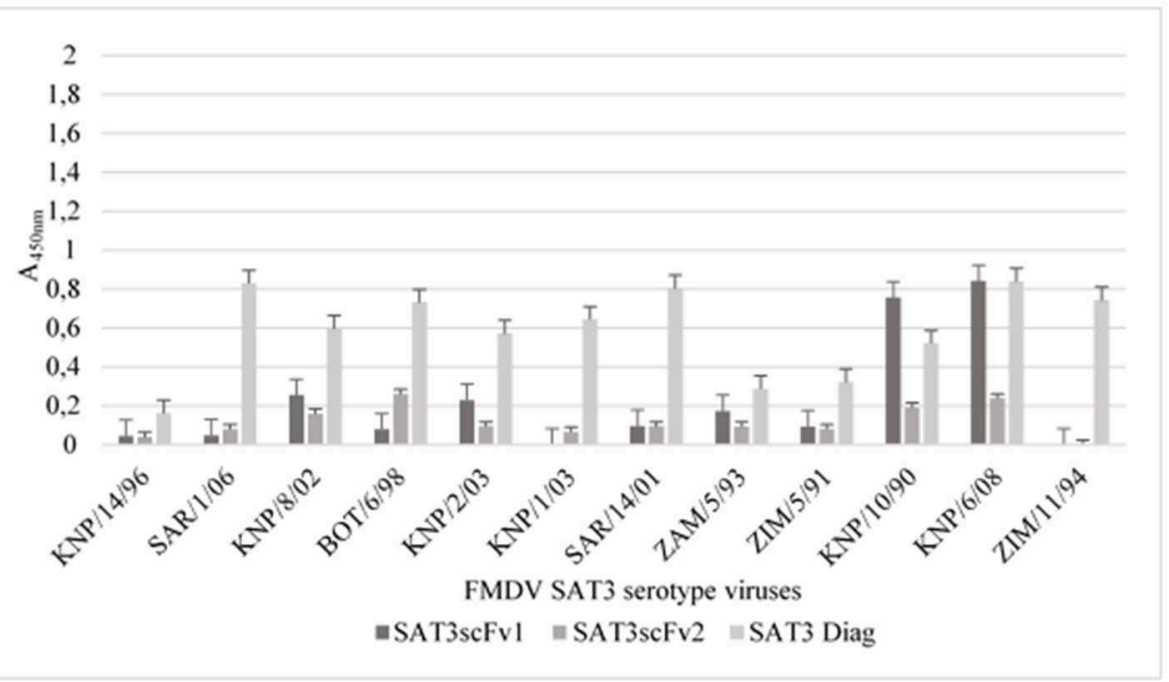

FIGURE 5 | Sandwich ELISA using soluble SAT1scFv1, SAT3scFV1, and SAT3scFV2 as detecting reagents. The standard diagnostic sandwich ELISA used for FMD antigen detection (46) [used as a positive control (SAT1 diag or SAT3 diag)] was adapted, where the detection antibody was replaced with a soluble SAT scFv. The ELISA was executed to determine the detecting potential of soluble SAT1scFv1 to PEG concentrated SAT1 viruses (A) and for SAT3scFv1 and SAT3scFV2 to PEG concentrated SAT3 serotype viruses (B). For the negative control, $2 \%$ milk powder was included in the assays replacing the virus component. The negative control ELISA background signal was deducted when plotting the ELISA A450nm result. The data are means \pm SD of two independent experiments.

Absorbance signals $\left(\mathrm{A}_{450 \mathrm{~nm}}\right)$ of 0.76 and 0.84 were observed for SAT3/KNP/10/90 and SAT3/KNP/6/08, respectively when SAT3scFv1 was the detecting antibody in the ELISA. All other $\mathrm{A}_{450 \mathrm{~nm}}$ values were below 0.26 for the SAT3 viruses tested with SAT3scFv1 and SAT3scFv2 (Figure 5B).

Taken together, the results indicate that the two SAT3 specific scFvs showed poor potential as a detecting ELISA antibody whilst conversely, SAT1scFv1 showed good potential for incorporation as a detecting antibody in a diagnostic ELISA.

\section{DISCUSSION}

Serotype-specific serological tests for FMD detect antibodies against the structural proteins that are elicited by either vaccination or infection (48). Both the solid-phase competition (SPCE) and LPBE ELISAs for SAT1, SAT2, and SAT3 are OIE recognized and well established assays. Considering the high genetic diversity of the SAT-type viruses $(2,6,26,49)$, there is a continuous need for improvement of these assays as crossreactivity has been noted with the SAT types using this assay. Additionally, for FMD vaccine matching where the antigenic variability of field virus strains is measured against current vaccine strains, the virus neutralization assay is utilized. This assay, however, is laborious and can cause a delay in decision making regarding FMD control measures. To address this shortcoming, utilizing MAbs or virus-specific scFv's for FMDV that recognize virus exposed antigenic epitopes in an ELISA format where results can be obtained timeously and accurately, 
was explored. These scFv's or small recombinant MAbs can be produced in large quantities (50) and can also be beneficial in predicting epitopes, which can in turn be used in the design of improved FMD chimeric vaccines containing various antigenic sites that can elicit a wide immunological response or protection in vaccinated animals. To this end, phage display technology was explored.

The $N k u k u^{\circledR}$ phage-display library has previously been panned on FMDV to obtain unique scFv binders for serotype SAT2 (25). Opperman et al. (25) has shown that one SAT2specific soluble $s c F v$ neutralized SAT2/ZIM/7/83. This $s c F v$ interacts with a novel epitope at residue position 159 of VP1 and was applied in a scFv-based ELISA assay. We broadened this study by including FMDV serotype SAT1, SAT3, and A. Using naïve phage display libraries allows for the selection of recombinant antibodies where unique paratopes bind to exposed and complementary parts of the immobilized antigen. Thus, the possibility of obtaining antigen-specific binders would depend on the presence and accessibility of suitable surface-exposed structures of the antigen, which in this case, was the FMD virion. Another factor to consider when using phage display technology, is that the quality and the size of the naive library plays an important role in the success of phage display (51), as paratopes that are not present within the library cannot be isolated.

In this study, the biopanning process with SAT1/KNP/196/91, SAT3/KNP/10/90, and A22 viruses resulted in unique FMDVspecific scFv binders i.e., one for SAT1, two for SAT3, and nine for serotype A. The nine A22 binders attained in this study is unique. Although none of the SAT scFv binders showed neutralization capability, three of the nine A22 binders exhibited neutralization. Of the three A22 neutralizing binders, two binders i.e., A22scFv1 and A22scFv8 had the same heavy chain sequences and only differed in the light chain region sequences. This characteristic is of interest as Hamers-Casterman et al. (52) showed that the $V_{H}$ play a more important role in the binding of antibody fragments to antigens than $\mathrm{V}_{\mathrm{L}}$. In addition, investigations by Williamson and Matthews (53) showed that three neutralizing scFvs against pertussis toxin all had the same heavy chain sequences and were related. Thus, to obtain more neutralizing scFvs, one could modify only the heavy chain of non-neutralizing scFvs of differing $\mathrm{V}_{\mathrm{Ls}}$ to be the same as their neutralizing counterparts.

For the generation of escape mutants for FMDV serotype A using the neutralizing scFvs, no aa changes were observed in the P1 region for SRV2, which may be because the mutation occurred in the minor population and due to Sanger sequencing, it was not detected. Additionally, the aa substitutions for SRV1 and SRV3 occurred in the surface exposed and structurally flexible VP1 $\beta G-\beta H$ loop, downstream of the RGD sequence. The position is identical to the identified FMDV serotype A antigenic site I and furthermore, the $\beta \mathrm{G}-\beta \mathrm{H}$ loop residues $140-160$ have been shown to play an important role in antigenicity in most FMDV serotypes (15-17, 19, 54-57). Additionally, changes at the conserved aa leucine residue 150 has also been shown i.e., $\mathrm{L} \rightarrow \mathrm{P}$ or $\mathrm{L} \rightarrow \mathrm{R}$ on escape mutants pressured by using soluble integrins $(58,59)$. SRV1 and SRV3 alone did not solve the binding footprint of the $\mathrm{A} 22 \mathrm{scFv} 1$ and A22scFv8 binders, respectively. It is reasonable to expect different binding footprints on the virion for the two
scFvs even though they have a common binding site at VP1 aa position 149/150. For SRV1, there was a Pro to Ser aa change at VP1 position 149 (RGD +3 position) and for SRV3 the aa change occurred at VP1 position 150, RGD+4 i.e., from a Leu to a Phe. The residues succeeding the RGD motif are important for receptor recognition $(58,60)$ and the RGD is flanked on both sides by hypervariable sequences, which delivers a domain that is capable of adopting different conformations. Both residues are highly conserved in serotype A viruses and the substitution of amino acid residues at position 149 or 150 of MAR-viruses have been described for $A_{10}, A_{12}$, and $A_{24}(15,16,57)$. Opperman et al. (25) showed with scFv neutralization investigations of FMDV SAT2/ZIM/7/83, an aa change at the base of the GH loop i.e., VP1 position 159 where there was an Arg to His change. Furthermore, a synthetic peptide ELISA confirmed VP1 aa 159 as an important residue in the epitope to which the SAT2 scFv binds (25). These investigations lead us to postulate that the epitope site for the A22scFv1 and A22scFv8 binding involves the VP1 aa position 149 and 150, respectively which is part of the antigenic sequence GDLGSLA for serotype A viruses (15). However, future investigations with SRV1 and SRV3, will be to derive a synthetic peptide from the predicted epitopic site and to confirm results with a synthetic peptide blocking ELISA.

A unique finding from this study is the result of two soluble, non-neutralizing scFvs, each from different FMDV serotypes but having the same heavy and light chain sequences i.e., SAT3scFv2 and A22scFv6. It is postulated that a common epitope between $\mathrm{SAT} 3 / \mathrm{KNP} / 10 / 90$ and A22 resulted in the same soluble scFv from the antibody repertoire of the $N k u k u^{\circledR}$ library. Neither of the two scFv's were able to neutralize the respective viruses and thus it was impossible to identify a binding site for the two scFv's on the viral capsid. Competing monoclonal antibody studies or capsid protein peptide libraries will be used to confirm the common or cross-reacting epitope between A22 and SAT3.

From the specificity analysis, the SAT1 and SAT3 soluble scFvs from this study bound to complete $146 \mathrm{~S}$ virions of the virus used for biopanning i.e., SAT1/KNP/196/91 and SAT3/KNP/10/90, respectively. However, the phage displayed $\mathrm{scFv}$ formats did show cross-reactivity across the FMD serotype viruses tested. The SAT1 phage displayed scFv was found to bind to complete $146 \mathrm{~S}$ virions of SAT2/ZIM/7/83 and SAT3/KNP/10/90 and similarly, the SAT3 phage-displayed scFvs were found to bind SAT1/KNP/196/91 and SAT2/ZIM/7/83 146S virions. Crossreactivity of scFvs is not uncommon as in a study by Toth et al. (61), which obtained $\mathrm{scFv}$ clones against the potato leafroll virus where 7 clones did not cross-react with other luteoviruses whilst 4 clones did. Additionally, Toth et al. (61) proved that the cross-reacting scFvs are directed against continuous epitopes that are present on the coat proteins of certain related luteoviruses whereas the scFvs that did not show cross-reactivity, bound to discontinuous or conformation-dependant epitopes that are specific to potato leafroll virus. A major continuous FMDV epitope is located in the GH loop spanning VP1 residues around positions 140-160 $(62,63)$. Thus, the cross-reacting phagedisplayed SAT1 and SAT3 scFvs from this study may possibly be recognizing continuous epitopes of the SAT serotype viruses and should be investigated further in this regard. 
The SAT soluble scFvs, which had reduced cross-reactivity compared to the phage displayed scFvs, were further investigated for their possible use as diagnostic reagents in an ELISA format as a FMDV capturing and a detecting reagent. For both ELISA formats, the one SAT1 soluble scFv was able to produce high reactivity to the various SAT1 PEG concentrated viruses tested implying that there was little or no effect on its paratope when coated on polystyrene plates and was thus a good capturing reagent. However, the two SAT3 scFvs produced $\mathrm{A}_{450 \mathrm{~nm}}$ signals just above the positive cut-off absorbance as a FMDV capturing reagent and a detecting reagent, which is not acceptable as a positive result for a diagnostic ELISA. It is vital for a capturing antibody in an ELISA assay to be efficiently immobilized onto the ELISA plate such that it is able to retain both the antibody conformation and the antigenbinding activity (64). Furthermore, important factors such as surface charge, hydrophobicity, co-adsorption of or exchange with surfactants, and other proteins play a role in determining stability and specificity of absorbed antibodies in ELISA assays $(65,66)$. These factors may have played a role to reduce the performance of the scFv ELISAs in this study. For conventional ELISAs where complete monoclonal or polyclonal antibodies are used, immobilization onto the ELISA plates occur via physical adsorption (66-69). Conversely, immobilization of small antibody fragments such as scFvs onto plastic surfaces causes unfavorable conformational changes to occur (66). Essentially, a hydrophobic interaction occurs in the linked $\mathrm{V}_{\mathrm{H}}$ and $\mathrm{V}_{\mathrm{L}}$ regions that forms a paratope resulting in a conformational change of the antigen-binding domain, which in turn results in decreased antigen-binding activity $(66,70,71)$.

The analytical specificity of the SAT scFvs for the capturing and detecting SAT1 and SAT3 ELISAs showed that the soluble scFvs were specific for the respective serotype viruses tested and no cross-reactivity was observed. Additionally, the analytical sensitivity of both the capturing and detecting ELISAs for SAT1 and SAT3 scFvs against the SAT1 and SAT3 viruses, respectively, was found to detect all PEG concentrated viruses at a 1:8 dilution tested albeit the low $\mathrm{A}_{450 \mathrm{~nm}}$ signals for the SAT3 scFv ELISAs. The SAT1scFv1 shows promise as a good detecting and immunocapture reagent due to the high reactivity for the SAT1 viruses tested. Studies have shown that when $s c F v$ fragments are utilized as a soluble protein and are not within the phage display system, low expression levels, or a low inherent affinity can occur (36). Also, the monomeric scFv fragments can have moderate binding affinities when binding to a large multivalent antigen like FMDV, which is in contrast to greater binding affinities that can be achieved by the multivalent display on the phage (7274). To overcome the low SAT3 scFv ELISA signals, random mutations can be introduced in the gene coding for the $\mathrm{scFv}$ and the length of the linker within the $\mathrm{scFv}$, increasing the bacterial expression of the scFvs and thus increasing the ELISA signal (41). Another approach is to stabilize the $s c F v$ to other proteins whilst retaining functionality. For example, fusion or linking to other proteins such as constant light chain domain (75), leucine zipper dimerization domain (76), Fc fragment $(\mathrm{CH} 2$ and $\mathrm{CH} 3$ domains) of mouse IgG1 (77), and alkaline phosphatase (78). Such approaches may be used in future studies to enhance the diagnostic potential of the SAT1 and SAT3 scFvs from this study.

This study has been beneficial to gain unique recombinant antibodies against FMDV SAT1, SAT3, and A serotype viruses. Although the SAT scFvs did not neutralize FMDV, the potential was shown as ELISA reagents, especially for SAT1scFv1. Further investigation and validations of SAT1scFv1 will be continued to improve ELISA absorbance signal.

\section{DATA AVAILABILITY STATEMENT}

The datasets presented in this study can be found in online repositories. The names of the repository/repositories and accession number(s) can be found in the article/supplementary material.

\section{AUTHOR CONTRIBUTIONS}

MC: majority of the experimental work, troubleshooting, result and data analysis, and manuscript composition and editing. PO: scFv expertise and training, experimental work, troubleshooting, result and data analysis, manuscript editing, and research grant acquisition. LR: serotype A experimental work, troubleshooting, result and data analysis, and manuscript editing. JFe and WW: scFv expertise advisor, Nkuku library, and manuscript editing. JFr: $s c F v$ column development, $s c F v$ purification training and expertise/advisor, and manuscript editing. ER: research grant acquisition, PI on grant at PIADC, project advisor, and manuscript editing. FM: research grant acquisition, PI on grant at $\mathrm{ARC}$, project advisor, scFv expertise, and manuscript editing. All authors contributed to the article and approved the submitted version.

\section{FUNDING}

Research findings documented in this paper are in part the results of a cooperative research and development grant between the Agricultural Research Council (ARC), Onderstepoort Veterinary Research (OVR) Institute of South Africa, and the U.S. Department of Agriculture, Agricultural Research Service, entitled Antigenic structure of FMDV capsid proteins and the selection of appropriate candidate vaccine strains in emerging FMD outbreaks (Grant No. 58-1940-0-107F).

\section{ACKNOWLEDGMENTS}

The authors would like to thank Prof. Jacques Theron for his critical scientific advice and inputs with this work as well as Dr. Tshifhiwa Nefefe and Mr. Nazeem Cassim for critical review of this manuscript. Additionally, we acknowledge the Serology and Immunochemistry Department at the ARC-OVR for provision of the $N k u k u^{\circledR}$ phage display library. The thesis by MC where this work first appeared [(79); URI: http://hdl.handle.net/2263/ 67975], was acknowledged. 


\section{REFERENCES}

1. Scott KA, Maake L, Botha E, Theron J, Maree FF. Inherent biophysical stability of foot-and-mouth disease SAT1, SAT2 and SAT3 viruses. Virus Res. (2019) 15:45-55. doi: 10.1016/j.virusres.2019.02.012

2. Knowles NJ, Samuel AR. Molecular epidemiology of foot-and-mouth disease virus. Virus Res. (2003) 91:65-80. doi: 10.1016/S0168-1702(02)00260-5

3. Mateu MG, Da Silva JL, Rocha E, De Brum DL, Alonso A, Enjuanes L, et al. Extensive antigenic heterogeneity of foot-and-mouth disease virus of serotype C. Virology. (1988) 167:113-24. doi: 10.1016/0042-6822(88)90060-8

4. Martínez MA, Dopazo J, Hernández J, Mateu MG, Sobrino F, Domingo E, et al. Evolution of the capsid protein genes of foot-and-mouth disease virus: antigenic variation without accumulation of amino acid substitutions over six decades. J Virol. (1992) 66:3557-65. doi: 10.1128/JVI.66.6.3557-3565.1992

5. Domingo E, Diez J, Martinez MA, Hernandez J, Holguin A, Borrego R, et al. New observations on antigenic diversification of RNA viruses: antigenic variation is not dependent on immune selection. J Gen Virol. (1993) 74 (Pt 10):2039-45. doi: 10.1099/0022-1317-74-10-2039

6. Maree FF, Blignaut B, Aschenbrenner L, Burrage T, Rieder E. Analysis of SAT1 type foot-and-mouth disease virus capsid proteins: influence of receptor usage on the properties of virus particles. Virus Res. (2011) 155:46272. doi: 10.1016/j.virusres.2010.12.002

7. Paton DJ, Sumption KJ, Charleston B. Options for control of foot-and-mouth disease: knowledge, capability and policy. Philos Trans R Soc Lond Ser B Biol Sci. (2009) 364:2657-67. doi: 10.1098/rstb.2009.0100

8. Kitching RP, Hutber AM, Thrusfield MV. A review of foot-and-mouth disease with special consideration for the clinical and epidemiological factors relevant to predictive modelling of the disease. Vet J. (2005) 169:197209. doi: 10.1016/j.tvjl.2004.06.001

9. Longjam N, Tayo T. Antigenic variation of foot and mouth disease virus - an overview. Vet World. (2011) 4:475-9. doi: 10.5455/vetworld.2011.475-479

10. McCullough KC, De Simone F, Brocchi E, Capucci L, Crowther JR, Kihm U. Protective immune response against foot-and-mouth disease. J Virol. (1992) 66:1835-40. doi: 10.1128/JVI.66.4.1835-1840.1992

11. Mateu MG, Hernández J, Martínez MA, Feigelstock D, Lea S, Pérez JJ, et al. Antigenic heterogeneity of a foot-and-mouth disease virus serotype in the field is mediated by very limited sequence variation at several antigenic sites. J Virol. (1994) 68:1407-17. doi: 10.1128/JVI.68.3.14071417.1994

12. Juleff ND. Interactions of foot-and-mouth disease virus with cells in organised lymphoid tissue influence innate and adaptive immune responses (thesis). The University of Edinburgh (2009). Available online at: http://hdl.handle.net/ $1842 / 4256$

13. Mahapatra M, Hamblin P, Paton DJ. Foot-and-mouth disease virus epitope dominance in the antibody response of vaccinated animals. J Gen Virol. (2012) 93 (Pt 3):488-93. doi: 10.1099/vir.0.037952-0

14. Taboga O, Tami C, Carrillo E, Núñez JI, Rodríguez A, Saíz JC, et al. A largescale evaluation of peptide vaccines against foot-and-mouth disease: lack of solid protection in cattle and isolation of escape mutants. J Virol. (1997) 71:2606-14. doi: 10.1128/JVI.71.4.2606-2614.1997

15. Thomas AAM, Woortmeijer RJ, Puijk W, Barteling SJ. Footand-mouth disease virus type A10. J Virol. (1988) 62:27829. doi: 10.1128/JVI.62.8.2782-2789.1988

16. Baxt B, Vakharia V, Moore DM, Franke AJ, Morgan DO. Analysis of neutralizing antigenic sites on the surface of type A12 foot-and-mouth disease virus. J Virol. (1989) 63:2143-51. doi: 10.1128/JVI.63.5.2143-2151.1989

17. Bolwell C, Clarke BE, Parry NR, Ouldridge EJ, Brown F, Rowlands DJ. Epitope mapping of foot-and-mouth disease virus with neutralizing monoclonal antibodies. J Gen Virol. (1989) 70 (Pt 1): 59-68. doi: 10.1099/0022-1317-70-1-59

18. Kitson JDA, McCahon D, Belsham GJ. Sequence analysis of monoclonal antibody resistant mutants of type $\mathrm{O}$ foot and mouth disease virus: evidence for the involvement of the three surface exposed capsid proteins in four antigenic sites. Virology. (1990) 179:26-34. doi: 10.1016/0042-6822(90)90269-W

19. Crowther JR, Rowe CA, Butcher R. Characterization of monoclonal antibodies against a type SAT 2 foot-and-mouth disease virus. Epidemiol Infect. (1993) 111:391-406. doi: 10.1017/S0950268800057083
20. Asfor AS, Upadhyaya S, Knowles NJ, King DP, Paton DJ, Mahapatra M. Novel antibody binding determinants on the capsid surface of serotype O foot-and-mouth disease virus. J Gen Virol. (2014) 95 (Pt 5):110416. doi: 10.1099/vir.0.060939-0

21. Mahapatra, M.ana, Yuvaraj S, Madhanmohan M, Subramaniam S, Pattnaik B, Paton DJ, Srinivasan VA, et al. Antigenic and genetic comparison of foot-and-mouth disease virus serotype $O$ Indian vaccine strain, O/IND/R2/75 against currently circulating viruses. Vaccine. (2015) 33:693700. doi: 10.1016/j.vaccine.2014.11.058

22. Mateu MG, Martínez MA, Capucci L, Andreu D, Giralt E, Sobrino F, et al. A single amino acid substitution affects multiple overlapping epitopes in the major antigenic site of foot-and-mouth disease virus of serotype C. J Gen Virol. (1990) 71 (Pt 3):629-37. doi: 10.1099/0022-1317-713-629

23. Sanyal A, Venkataramanan R, Pattnaik B. Antigenic features of footand-mouth disease virus serotype Asial as revealed by monoclonal antibodies and neutralization-escape mutants. Virus Res. (1997) 50:10717. doi: 10.1016/S0168-1702(97)00058-0

24. Grazioli S, Moretti M, Barbieri I, Crosatti M, Brocchi E. Use of Monoclonal Antibodies to Identify and Map New Antigenic Determinants Involed in Neutralization of FMD Viruses Type SAT 1 and SAT 2. Paphos: European Commission for the Control of Foot-and-Mouth Disease: International Control of Foot-and-Mouth Disease: Tools, Trends and Perspectives (2006). p. 287-297.

25. Opperman PA, Maree FF, Van Wyngaardt W, Vosloo W, Theron J. Mapping of antigenic determinants on a SAT2 foot-and-mouth disease virus using chicken single-chain antibody fragments. Virus Res. (2012) 167:3709. doi: 10.1016/j.virusres.2012.05.026

26. Maree FF, Kasanga CJ, Scott KA, Opperman PA, Chitray M, Sangula $\mathrm{AK}$, et al. Challenges and prospects for the control of foot-andmouth disease: an African perspective. Vet Med Res Rep. (2014) 5:11938. doi: 10.2147/VMRR.S62607

27. Davidson FL, Crowther JR, Nqindi J, Knowles NJ, Thevasagayam SJ, Van Vuuren CJ. Antigenic analysis of SAT 2 serotype footand-mouth disease virus isolates from Zimbabwe using monoclonal antibodies. Epidemiol Infect. (1995) 115:193-205. doi: 10.1017/S095026880 005826X

28. Opperman P. Antigenic site determination on a SAT2 foot-and-mouth disease virus using a chicken antibody phage display library by P.A Opperman (thesis). University of Pretoria, Pretoria, South Africa (2013).

29. Xie QC, McCahon D, Crowther JR, Belsham GJ, McCullough KC. Neutralization of foot-and-mouth disease virus can be mediated through any of at least three separate antigenic sites. J Gen Virol. (1987) (Pt 6):163747. doi: 10.1099/0022-1317-68-6-1637

30. Acharya R, Fry E, Stuart D, Fox G, Rowlands D, Brown F. The threedimensional structure of foot-and-mouth disease virus at $2.9 \mathrm{~A}$ resolution. Nature. (1989) 337:709-16. doi: 10.1038/337709a0

31. Dunn CS, Samuel AR, Pullen LA, Anderson J. The biological relevance of virus neutralisation sites for virulence and vaccine protection in the guinea pig model of foot-and-mouth disease. Virology. (1998) 247:5161. doi: 10.1006/viro.1998.9175

32. Köhler G, Milstein C. Continuous cultures of fused cells secreting antibody of predefined specificity. Nature. (1975) 256:495-7. doi: 10.1038/256495a0

33. Willats WGT. Phage display: practicalities and prospects. Plant Mol Biol. (2002) 50:837-54. doi: 10.1023/A:1021215516430

34. Pandey S. Hybridoma technology for the production of monoclonal antibodies. Int J Pharmac Sci Rev Res. (2010) 1:88-94.

35. Smith GP, Petrenko VA. Phage display. Chem Rev. (1997) 97:391410. doi: $10.1021 / \mathrm{cr} 960065 \mathrm{~d}$

36. van Wyngaardt W, Malatji T, Mashau C, Fehrsen J, Jordaan F, Miltiadou $\mathrm{D}$, et al. A large semi-synthetic single-chain $\mathrm{Fv}$ phage display library based on chicken immunoglobulin genes. BMC Biotechnol. (2004) 4:6. doi: 10.1186/1472-6750-4-6

37. Harmsen MM, van Solt CB, Fijten HPD, van Keulen L, Rosalia RA, Weerdmeester $\mathrm{K}$, et al. Passive immunization of guinea pigs with llama single-domain antibody fragments against foot-and-mouth disease. Vet Microbiol. (2007) 120:193-206. doi: 10.1016/j.vetmic.2006. 10.029 
38. Yu Y, Wang H, Zhao L, Zhang C, Jiang Z, Yu L. Fine mapping of a foot-andmouth disease virus epitope recognized by serotype-independent monoclonal antibody 4B2. J Microbiol. (2011) 49:94-101. doi: 10.1007/s12275-0110134-1

39. Fehrsen J, van Wyngaardt W, Mashau C, Potgieter AC, Chaudhary VK, Gupta A, et al. Serogroup-reactive and type-specific detection of bluetongue virus antibodies using chicken scFvs in inhibition ELISAs. J Virol Methods. (2005) 129:31-9. doi: 10.1016/j.jviromet.2005.04.015

40. Rakabe M. Selection of chicken single-chain antibody fragments directed against recombinant VP7 of bluetongue virus (thesis). University of Pretoria, Pretoria, South Africa (2008). p. 1-111. doi: 10.1080/09540105.2011.575122

41. Sixholo J, Van Wyngaardt W, Mashau C, Frischmuth J, Du Plessis DH, Fehrsen J. Improving the characteristics of a mycobacterial $16 \mathrm{kDa}$-specific chicken scFv. Biologicals. (2011) 39:110-6. doi: 10.1016/j.biologicals.2011. 01.007

42. Nukarinen T. Production and characterisation of $s c F v$ binders against selected Enteroviruses by T Nukarinen (thesis). University of Eastern Finland, Joensuu, Finland (2016).

43. Knipe T, Rieder E, Baxt B, Ward G, Mason PW. Characterization of synthetic foot-and-mouth disease virus provirions separates acid-mediated disassembly from infectivity. J Virol. (1997) 71:2851-6. doi: 10.1128/JVI.71.4.2851-2856.1997

44. Doel TR, Mowat GN. An international collaborative study on foot and mouth disease virus assay methods. 2. Quantification of $146 \mathrm{~S}$ particles. J Biol Stand. (1985) 13:335-44. doi: 10.1016/S0092-1157(85)80048-2

45. Hall T. BioEdit sequence alignment editor for windows 95/98/NT/XP/Vista/7. Nucleic Acids Sympos Ser. (1999) 41:95-8.

46. Office International des Epizooties. Principles and Methods of Validation of Diagnostic Assays for Infectious Diseases. Manual of Diagnostic Tests and Vaccines for Terrestrial Animals 2018 (2018).

47. Lea S, Abu-Ghazaleh R, Blakemore W, Curry S, Fry E, Jackson T, et al. Structural comparison of two strains of foot-and-mouth disease virus subtype O1 and a laboratory antigenic variant, G67. Structure. (1995) 3:57180. doi: 10.1016/S0969-2126(01)00191-5

48. Namatovu A, Belsham GJ, Ayebazibwe C, Dhikusooka MT, Wekesa SN, Siegismund HR, et al. Challenges for serology-based characterization of footand-mouth disease outbreaks in Endemic areas; identification of two separate lineages of serotype O FMDV in Uganda in 2011. Transbound Emer Dis. (2015) 62:522-34. doi: 10.1111/tbed.12170

49. van Rensburg HG, Nel LH. Characterization of the structural-protein-coding region of SAT 2 type foot-and-mouth disease virus. Virus Genes. (1999) 19:229-33. doi: 10.1023/A:1008140815045

50. Ahmad ZA, Yeap SK, Ali AM, Ho WY, Alitheen NBM, Hamid M. ScFv antibody: Principles and clinical application. Clin Develop Immunol. (2012) 2012:980250. doi: 10.1155/2012/980250

51. Carmen S, Jermutus L. Concepts in antibody phage display. Brief Funct Genomics Proteomics. (2002) 1:189-203. doi: 10.1093/bfgp/1.2.189

52. Hamers-Casterman C, Atarhouch T, Muyldermans S, Robinson G, Hamers C, Songa EB, et al. Naturally occurring antibodies devoid of light chains. Nature. (1993) 363:446-8. doi: 10.1038/363446a0

53. Williamson P, Matthews R. Development of neutralising human recombinant antibodies to pertussis toxin. FEMS Immunol Med Microbiol. (1999) 23:3139. doi: 10.1016/S0928-8244(98)00151-5

54. Pfaff E, Thiel HJ, Beck E, Strohmaier K, Schaller H. Analysis of neutralizing epitopes on foot-and-mouth disease virus. J Virol. (1988) 62:203340. doi: 10.1128/JVI.62.6.2033-2040.1988

55. Barnett PV, Ouldridge EJ, Rowlands DJ, Brown F, Parry NR. Neutralizing epitopes of type $\mathrm{O}$ foot-and-mouth disease virus. I. Identification and characterization of three functionally independent, conformational sites. J Gen Virol. (1989) 70 (Pt 6):1483-91. doi: 10.1099/0022-1317-706-1483

56. Parry NR, Barnett PV, Ouldridge EJ, Rowlands DJ, Brown F. Neutralizing epitopes of type $\mathrm{O}$ foot-and-mouth disease virus. II Mapping three conformational sites with synthetic peptide reagents. J Gen Virol. (1989) 70:1493-503. doi: 10.1099/0022-1317-70-6-1493

57. Mahapatra M, Seki C, Upadhyaya S, Barnett PV, La Torre J, Paton DJ. Characterisation and epitope mapping of neutralising monoclonal antibodies to A24 Cruzeiro strain of FMDV. Vet Microbiol. (2011) 149:2427. doi: 10.1016/j.vetmic.2010.11.003
58. Rieder E, Baxt B, Mason PW. Animal-derived antigenic variants of foot-and-mouth disease virus type A12 have low affinity for cells in culture. J Virol. (1994) 68:5296-9. doi: 10.1128/JVI.68.8.5296-529 9.1994

59. Lawrence P, Larocco M, Baxt B, Rieder E. Examination of soluble integrin resistant mutants of foot-and-mouth disease virus. Virol J. (2013) 10:2. doi: 10.1186/1743-422X-10-2

60. Jackson T, Sheppard D, Denyer M, Blakemore W, King AMQ. The epithelial integrin $\alpha v \beta 6$ is a receptor for foot-and-mouth disease virus. J Virol. (2000) 74:4949-56. doi: 10.1128/JVI.74.11.4949-4956.2000

61. Toth RL, Harper K, Mayo MA, Torrance L. Fusion proteins of singlechain variable fragments derived from phage display libraries are effective reagents for routine diagnosis of potato leafroll virus infection in potato. Phytopathology. (1999) 89:1015-21. doi: 10.1094/PHYTO.1999.89.11.1015

62. Bittle JL, Houghten RA, Alexander H, Shinnick TM, Sutcliffe JG, Lerner RA, et al. Protection against foot-and-mouth disease by immunization with a chemically synthesized peptide predicted from the viral nucleotide sequence. Nature. (1982) 298:30-3. doi: 10.1038/298030a0

63. Pfaff E, Mussgay M, Böhm HO, Schulz GE, Schaller H. Antibodies against a preselected peptide recognize and neutralize foot and mouth disease virus. EMBO J. (1982) 1:869-74. doi: 10.1002/j.1460-2075.1982.tb01262.x

64. Jung Y, Jeong JY, Chung BH. Recent advances in immobilization methods of antibodies on solid supports. Analyst. (2008) 133:697701. doi: 10.1039/b800014j

65. Qian W, Yao D, Yu F, Xu B, Zhou R, Bao X, et al. Immobilization of antibodies on ultraflat polystyrene surfaces. Clin Chem. (2000) 46:145663. doi: 10.1093/clinchem/46.9.1456

66. Kumada Y, Ishikawa Y, Fujiwara Y, Takeda R, Miyamoto R, Niwa D, et al. Efficient refolding and immobilization of PMMA-tag-fused single-chain Fv antibodies for sensitive immunological detection on a PMMA plate. $J$ Immunol Methods. (2014) 411:1-10. doi: 10.1016/j.jim.2014.05.015

67. McCullough KC, Crowther JR, Butcher RN. Alteration in antibody reactivity with foot-and-mouth disease virus (FMDV) $146 \mathrm{~S}$ antigen before and after binding to a solid phase or complexing with specific antibody. J Immunol Methods. (1985) 82:91-100. doi: 10.1016/0022-1759(85)90228-5

68. Kumada Y, Hamasaki K, Shiritani Y, Nakagawa A, Kuroki D, Ohse T, et al. Direct immobilization of functional single-chain variable fragment antibodies (scFvs) onto a polystyrene plate by genetic fusion of a polystyrene-binding peptide (PS-tag). Analyt Bioanalyt Chem. (2009) 395:759-65. doi: 10.1007/s00216-009-2999-y

69. Kumada Y, Hamasaki K, Shiritani Y, Ohse T, Kishimoto M. Efficient immobilization of a ligand antibody with high antigen-binding activity by use of a polystyrene-binding peptide and an intelligent microtiter plate. $J$ Biotechnol. (2009) 142:135-41. doi: 10.1016/j.jbiotec.2009.03.011

70. Torrance L, Ziegler A, Pittman H, Paterson M, Toth R, Eggleston I. Oriented immobilisation of engineered single-chain antibodies to develop biosensors for virus detection. J Virol Methods. (2006) 134:16470. doi: 10.1016/j.jviromet.2005.12.012

71. Wemmer S, Mashau C, Fehrsen J, van Wyngaardt W, du Plessis DH. Chicken scFvs and bivalent scFv-C(H) fusions directed against HSP65 of Mycobacterium bovis. Biologicals. (2010) 38, 407-414. doi: 10.1016/j.biologicals.2010.02.002

72. Hoogenboom HR, Winter G. By-passing immunisation. Human antibodies from synthetic repertoires of germline $\mathrm{VH}$ gene segments rearranged in vitro. J Mol Biol. (1992) 227:381-8. doi: 10.1016/0022-2836(92)90894-P

73. Griffiths AD, Malmqvist M, Marks JD, Bye JM, Embleton MJ, McCafferty J, et al. Human anti-self antibodies with high specificity from phage display libraries. EMBO J. (1993) 12:725-34. doi: 10.1002/j.1460-2075.1993.tb05706.x

74. O'Connell D, Becerril B, Roy-Burman A, Daws M, Marks JD. Phage versus phagemid libraries for generation of human monoclonal antibodies. J Mol Biol. (2002) 321:49-56. doi: 10.1016/S0022-2836(02)00 $561-2$

75. Mcgregor DP, Molloy PE, Cunningham C, Harris WJ. Spontaneous assembly of bivalent single chain antibody fragments in Escherichia coli. Mol Immunol. (1994) 31:219-26. doi: 10.1016/0161-5890(94)90002-7

76. Griep RA, Prins M, van Twisk C, Keller HJ, Kerschbaumer RJ, Kormelink $\mathrm{R}$, et al. Application of phage display in selecting Tomato spotted wilt virusspecific Single-Chain Antibodies (scFvs) for sensitive diagnosis in ELISA. Phytopathology. (2000) 90:183-90. doi: 10.1094/PHYTO.2000.90.2.183 
77. Liu J, Wei D, Qian F, Zhou Y, Wang J, Ma Y, et al. pPIC9-Fc: a vector system for the production of single-chain Fv-Fc fusions in Pichia pastoris as detection reagents in vitro. J Biochem. (2003) 134:911-7. doi: 10.1093/jb/ $\operatorname{mvg} 222$

78. Kerschbaumer RJ, Hirschl S, Kaufmann A, Ibl M, Koenig R, Himmler G. Single-chain Fv fusion proteins suitable as coating and detecting reagents in a double antibody sandwich enzyme-linked immunosorbent assay. Analyt Biochem. (1997) 249:219-27. doi: 10.1006/abio. 1997.2171

79. Chitray M. Improvement of foot-and-mouth disease virus vaccines and diagnostics through structural design (thesis). University of Pretoria, Pretoria, South Africa (2018).
Conflict of Interest: The authors declare that the research was conducted in the absence of any commercial or financial relationships that could be construed as a potential conflict of interest.

Copyright (c) 2020 Chitray, Opperman, Rotherham, Fehrsen, van Wyngaardt, Frischmuth, Rieder and Maree. This is an open-access article distributed under the terms of the Creative Commons Attribution License (CC BY). The use, distribution or reproduction in other forums is permitted, provided the original author(s) and the copyright owner(s) are credited and that the original publication in this journal is cited, in accordance with accepted academic practice. No use, distribution or reproduction is permitted which does not comply with these terms. 